\title{
Writing In/Difference to the M/Other: \\ Kusama Yayoi's Prose as Proto-Feminist Agency
}

\author{
Stefan Würrer
}

\begin{abstract}
This paper presents an attempt to critically investigate the literary work of Japanese artist Kusama Yayoi (b. 1929). It takes as its object two of Kusama's early prose texts and, by reading them through a feminist account of identity as fetishism, shows that the two novels presented in this paper-Kurisutofā danshō kutsu (1984) and Rijin kāten no shūjin (1984)—can be understood as a critical engagement with a potentially non-normative feminine self and, in a broader sense, as a negotiation of the state of being a woman in a patriarchal/androcentric society. These features can be traced back to her 1960s sculptural work and her Infinity Net Paintings. By not only situating Kusama's literary work in a socio-historical context but also demonstrating that it constitutes an intertextual continuum with the rest of her artistic oeuvre, this paper offers an understanding of Kusama's work besides the dominant narrative of her mental illness and lays the ground for further investigations into her literary texts.
\end{abstract}

Keywords: Kusama Yayoi, contemporary art, contemporary literature, feminism, mental illness Proto-Feminist Agency." In Vienna Journal of East Asian Studies, Volume 8, eds. Rudiger Frank, Ina Hein, Lukas Pokorny, and Agnes Schick-Chen. Vienna: Praesens Verlag, 2016, pp. 227-266.

https://doi.org/10.2478/vjeas-2016-0008 


\section{Introduction}

Mostly known for her white, grey, or milk-coloured Infinity Net Paintings and softobjects/sculptures covered with phallus-like protuberances, the Japanese artist Kusama Yayoi 草間彌生, from the mid-1970s onwards, has also written a vast amount of prose and poetry. Amongst the $22^{1}$ prose texts she published until 1999, her Burroughs-esque debut work Manhattan jisatsu-misui-jōshūhan マンハッタン自 殺未遂常習犯 (The Manhatten Suicide Addict, 1978) and the short story Kurisutofā dansho kutsu クリストファー男娼窟 (The Hustler's Grotto of Christopher Street, 1984; hereafter referred to as $K D$ ) have gained attention by literary critics, with the latter being awarded the tenth Yasei jidai shinjin bungaku sho 野生時代新人文学賞 (Yasei Jidai Literary Award for New Writers) in 1983 by a selection committee, including Nakagami Kenji 中上健次 and Murakami Ryū 村上龍 (Munroe 1998: 70).

However, Kusama's literary work has gone nearly unnoticed within academia until today. There do exist two essays which exclusively deal with Kusama's prose and poetry (Munroe 1998; Hayashi 2007). Both, unfortunately, while undoubtedly important as introductory texts, lack a close reading of Kusama's stories themselves and show a tendency towards a psychological biographism that once and again overemphasises (the narrative of) Kusama's mental illness. This paper will attempt to fill in this blank by analysing two of Kusama's earlier prose texts-Rijin kāten no shüjin 離人カーテンの囚人 (Prisoner of the Curtains of Depersonalisation, 1984; herafter referred to as $R K N S$ ) and $K D$-in the context of feminist thought and the broader framework of her artistic production. The aim is to thus highlight possibilities of how to approach Kusama's literary work. ${ }^{2}$

\section{Historicising Kusama}

As Gunhild Borggreen has noted, '[a]nyone with the slightest interest in the art of Kusama Yayoi will have encountered parts of a discourse concerning madness and insanity' (2000: 11). This is mainly due to the fact that Kusama herself, as Munroe points out, 'has claimed in numerous interviews and statements over the last fifty years' (1998: 72) that the obsessions and hallucinatory experiences she suffers from since her childhood - so Kusama explicates for instance in her autobiography - form the driving force behind her art production (see e.g. Kusama 1975; 2011: 61-66). This is the narrative that has come to dominate the scholarly and non-scholarly

1 For a list of Kusama's literary work see the Appendix.

2 This paper is based on my master thesis (Würrer 2015a). It further explicates and supplements some of the arguments presented in an essay for the catalogue of the Kusama exhibition at the Louisiana Museum of Modern Art in Copenhagen (Würrer 2015b). 
discourse on her work (cf. Borggreen 2001: 15), as is the case with Alexandra Munroe's essay on Kusama's literary work. In the first half of her analysis, Munroe attempts to situate Kusama's fiction within modern and contemporary Japanese literature by pointing out what she deems to be similarities between Kusama's literary texts and those by Izumi Kyōka 泉鏡花, Nakagami Kenji, Murakami Ryū, as well as surrealists like Takiguchi Shuzō 瀧口修造 or even the Japanese puppet theatre bunraku 文楽 (1998: 72-78). Unfortunately, however, we do not find much evidence for her claims besides a few sketchy comparisons. Also, the broad range of the objects of comparison rather hinders than enables further investigations into where to place Kusama's fiction within Japanese literature. Furthermore, those vague hints in the end get overwritten by a variant of the mental-illness-narrative when Munroe, in the second half of her essay, states that '[t]he true subject of Kusama's fiction is trauma' (ibid.: 80), and that 'as Kusama grew more familiar through psychiatric treatment with the formal symptoms of her illness and more analytically aware of its childhood sources, her art became to a greater and greater extent the literal working-out of her disorders ${ }^{3}$ (ibid.: 81). Munroe acknowledges that 'trauma must be substantially transformed before it can communicate to others as beauty and meaning' (ibid.) yet does not provide us with a detailed reading of, for instance, how the recurring motive of castration or hallucinating female characters functions within the text, other than being "therapeutic" reproductions of childhood traumata. Munroe's essay, therefore, effectively confines the semiosis of Kusama's texts to being a spyhole into the "personal" world of her mental illness and, in doing so, mirrors the discourse on Kusama's art, with its fetishistic mystification of Kusama as the "mad artist" (cf. Pollock 2000: 108-109; Borggreen 2001: 10-14). In other words, to argue that Kusama's literary language rather than being a deployment of, for instance, the contexts of modern and contemporary literature, is 'the literal working-out of her disorders', is to reproduce and make iterable a discourse that establishes "proof" for the individual, hence, original nature of Kusama's work without having to situate her within —or, respectively, displace her at the outskirts of - (literary) history. This kind of argumentation does not only bring to mind the romanticist question of 'genius or madman'; it also uncannily parallels in its fetishistic structure - that is, by acknowledging the historical potential of the female artistic text while simultaneously disavowing it by overwriting it with "mental illness" (A rather than B) - the androcentric writing of modern art and literary history (and sanity) in Japan and elsewhere, with its equation of female artistry with deviance, irrationality, emotionality, the private, etc. and the seclusion of female artists as 'special cases' (Borggreen 2003: 184) in epistemological ghettos, such as jory $\bar{u}$ bijutsu 女流美術 (woman's art; cf. Godzik 2006: 44-45; Nochlin 1988: 152; Pollock 1988: 33-34).

3 Italics in quotations, if not noted otherwise, are by the author and used for emphasis. 
What then becomes necessary in an analysis of Kusama's literary work is an approach similar to the one Griselda Pollock argues for, when she, with regard to Kusama's visual art of the 1960s, writes that we need to

\begin{abstract}
allow Yayoi Kusama's artistic text to function historically as the index of an artistic presence shaped by the intense but historically forged dislocated-ness afflicting the tripled alterity of being a Japanese woman artist during the pre-feminist, pre-difference moment of New York in the sixties (2000: 108).
\end{abstract}

Although also showing a tendency towards psychological biographism similar to Munroe's, Hayashi Yōko's text on Kusama's literature hints at the possibility of such an approach. Reminiscent of Tomii Reiko's characterisation of Kusama's art production as Gesamtkunstwerk (Tomii 1997: 21), Hayashi points out the intertextual relationships between the various media employed by Kusama, whom she sees as an artist who 'traverses art and literature' (2007: 137). She argues that the topics Kusama's novels deal with - e.g. homosexuality, incest, prostitution, drug abuse, suicide etc.-back at the time they were published were still regarded as being scandalous when brought up by a woman and that, in doing so, her novels 'are even more direct, more sexual, more provocative than her [visual] $\operatorname{art}^{\circ 4}$ (ibid.: 142). It is left unclear what art works Hayashi sees reworked or referenced to in Kusama's prose but, given its feminist overtone, one could assume that what is referred to here is precisely the Kusama functioning within history that Pollock is writing about and that has been overwritten ever so often: A Kusama in artistic negotiation with sociohistorical discourses, a Kusama in opposition to an androcentric, patriarchal (art-) world.

\title{
Proto-Feminist Pharmakon
}

Looking back at her youth in the early Shōwa 昭和 years, Kusama wrote in her autobiography: 'According to the conventional wisdom of the time, a woman had no future as a painter.' 'This wisdom', she adds, 'held particular sway in an oldfashioned family like mine' (2011: 71). Born in 1929 in Matsumoto, Nagano 長野 prefecture, Kusama was thirteen when the Imperial Japanese Navy attacked Pearl Harbour - her youth, therefore, was not only dominated by conservative feudalistic gender norms but also by militarism and imperialism. 'I suffered. It killed my mind', she once stated with regard to the militarism during the Pacific War (Munroe 1989: 13); and it was the outrage and frustration she experienced in reaction to those multiple oppressions - to 'patriarchal domination and the pressures of social conformity' - that from a young age onwards 'became identical with the expression of 
her character and in time, of her art' (ibid.). The manifold hardships female artists had to face in the androcentric, patriarchal post-war art world (cf. Kusama 2011: 75; Godzik 2006: 197-202) and more generally in Japanese society as such then led Kusama - among other female artists, such as Ōno Yōko 小野洋子 and Kubota Shigeko 久保田茂子- to leave behind Japan and its social norms, such as that of the ryōsai kenbo 良妻賢母 ("good wife and wise mother"), a 'prewar ideology of femininity, that found renewed relevance in the postwar period' (Bullock 2010: 18) and move to New York in search for (artistic) freedom (Yoshimoto 2005: 4). However, New York's art scene in the 1960s was deeply misogynistic and 'an excruciably difficult place for women artists' as well (Zelevansky 1999: 24). The ever so proliferating phallic form, as seen for instance in soft-sculptures such as Accumulation No.2, together with the fact that it first appeared in Kusama's work a few years after her immigration to New York, could therefore be seen as a negotiation with the adverse circumstances - e.g. as a parody of the phallocentric (art-)world—she was confronted with as a female artist at that time (ibid.: 18, 24).

When Hayashi then writes of Kusama's fiction as being 'more provocative than her [visual] art', one could rightly assume that what she refers to is Kusama's work of this period. It is, of course, as is already implied in Pollock's remark, difficult to determine to what extent Kusama was aware of feminist thought back then and, by extension, to what degree in her art she consciously dealt with the difficulties a female artist faced in order to survive within a male-dominated (art-)world (Pollock 2000: 108, cf. Zelevansky 1999: 24; Dawsey 2009: 54). This is particularly because what later came to be known as second wave feminism was just starting to emerge at the time Kusama lived in New York (1957-1973) and the language barrierKusama states that she had not studied English before going to the United States (Kusama 2011:11) - also limited access to existent discourses on gender and sexuality.

Nevertheless, can we claim at least for Kusama's work a certain kind of feminist agency, even if that might be problematic with regard to Kusama herself? As we know at least since Judith Butler, gender is not the intentional expression and embodiment of an essential biological core. It has to be understood as a discursive construct that is the intelligible effect of iterative performance, the repeated approximation of the subject-in-making to normative and normativising ideological constructs such as "feminine" and "masculine" (Butler 1993: 1-23). The (female) artist, as a gendered subject, therefore, is always already torn between the necessity to react towards the manifold appellations on part of the normativising discourse with intelligible self-fashioning and those oppositional, potentially norm-subverting parts of the I that do not or cannot find their expression within it (cf. Butler 1995: 6-7); a

5 For more on this ideology and how it was revived in the post-war period see, for instance, Bullock 2010: 13-31. 
conflict that necessarily informs artistic production too. For female artists this may be especially the case when being-woman is socially construed as the "other" vis-àvis the man, for example, when it is confined to being the object of male desire and maternalistic ideology. If we then, as Pollock does in Vision and Difference, not only take art in the abstract but also the individual art work as the inter-textual product of subjects being constituted by as well as (re-)constituting ideology (1988: 12-55), Kusama's art can be understood as incorporating traces of the daily confrontation with androcentric and phallocentric ideology and as such, as Jill Dawsey has put it, could be read as 'proto-feministic artistic vocabulary' (2009: 29).

The same might be said about Kusama's novels, when we consider the conditions under which she increasingly devoted herself to literature from the mid-1970s onwards. On one of the few occasions she mentions her literary work, Kusama says that art and writing for her are 'essentially the same thing' (2011: 206), but goes on to add that 'through writing novels and poems in Japanese, I was able to shed light on a different facet of myself, one that I could not reach with plastic arts' (ibid.). We are left in the dark about what exactly this different facet is, yet read again in combination with a comment by Seki Naoko, Kusama's remark points in the direction of yet another incident of "one" Kusama being overwritten by "another": Seki argues that in her novels we find reworked Kusama's sixties, that is, that writing novels was a way for Kusama to fill the blank her emigration to the United States has resulted in in Japan (1999: 164). Given the difficulties Kusama faced after her return to Japan in 1973 , this makes perfect sense. For what made the beginning of the 1970s so difficult for her was in large part the moribund task to make comprehensible her artistic work/self to Japanese society, or rather to differentiate herself from the Kusama she was remembered for: The notoriously 'shameless' woman, who stripped in public on the streets of New York and Tōkyō.

Kusama's name had - especially around the time of her three-month stay in Japan in 1970 - appeared almost exclusively in the context of nude happenings, body painting events, and public demonstrations, which her artistic production focused on at that time. Ignored by the Japanese art world, however, these were mainly made the object of sensationalist, sexist reporting by the Japanese mass media, which reduced them to the naked female body and branded them as harenchi 破廉恥 ("shameless") (Karia 1989: 95; Kusama 2011: 143-145; Watanabe 1993: 101-102; Zelevansky 1999: 27). Although the social conditions for women in terms of gaining access to education and choosing marital partners for themselves had clearly improved during the course of the democratisation process in the years after the Pacific War, the image of women in Japan in the 1960s was nevertheless still dominated by the ideal of woman as (chaste) wife and (caring) mother. Unmarried female artists like Kusama, who in addition placed their (naked) bodies at the centre of their art, were - if existent at all-thus considered deviationists per se and found themselves confronted with a reduction of their artistic activity to what was intelligible to 
Japanese society at that time: the female body as an object of male desire (cf. Bullock 2010: 19-30; Kuroda 2010: 402-408). In 1970, Kusama vented her anger about the conditions at the time in a magazine article as follows:

\begin{abstract}
Right now I'd really like to take a baseball bat and give the Japanese men a good hiding. Castrate them all and then off with them to exile on the island of Hachijō! True, if one looks at Japanese magazines, they are inundated with pictures of nude women and articles about sex. But certainly, this is no reason to speak of sexual revolution. My grandmothers and my mother were among those who saved themselves for their husbands alone. What could be more foolish? Rather than allowing yourself to be shackled by public opinion and old-fashioned morality and simply waiting to become someone's bride, a woman should pack her suitcase and set off on her own to do what she loves in life, even if it means begging for food and sleeping outdoors (Kusama 1970: 44, cited in translation in Würrer 2015b: 78).
\end{abstract}

Given this, could we then not think of Kusama's turning to literature and, by extension, of her earlier prose as something like an artistic proto-feminist pharmakon, that is, as ' $[\mathrm{b}] \mathrm{oth}$ sign of the poison of and a cure for an impossible situation' (Pollock 2000: 108) with which she saw herself confronted as a female artist after her return to Japan?

In the following I will argue exactly that. In order to do so, I will first lay out the theoretical framework that informs this study by giving a brief example of how Carol-Ann Tyler's account of identity as 'fetishism of imposture' and mimicry allows us to understand certain works of Kusama's visual art as an instance of female fetishism and proto-feminist pharmakon. Based on this, I will then analyse the stratification of gender in the above mentioned early novels by Kusama. Both are representative of Kusama's work not only as being the two most reprinted and well known of her novels (cf. Appendix), but also because each one is the first short story of the two categories Kusama's prose texts can be divided into, namely those set in Japan and those set in the United States (Hayashi 2007: 135). By situating these texts within feminist thought, I will demonstrate that those novels rework, as Hayashi and Seki suggest, her other artistic work and that in doing so they can be read as a critical engagement with the potentially non-normative feminine self and a negotiation on the state of being a woman in a patriarchal/androcentric society more generally.

6 私は今、日本の男性のおしりを野球バットで殴ってやりたい気持ちです。全部去勢して八丈島に島流しで す。日本の雑誌をみると、なるほど、女性の裸やセックス記事が氾監しています。しかしそれでセックスの 革命が進んでいるわけではありません。私の祖母や母たちは、夫だけに貞操をさげていました。そんなバ カなことがあるでしょうか。世間の目や、古い道徳にしばられて、ただお嫁に行くのを待つよりは、スーツケ 一スひとつさげて、乞食をしても野宿をしても、自分の好きなことをして生きるべきです。 


\section{Female Fetishism in Kusama Yayoi's Visual Art}

As Carol-Ann Tyler elaborates in her critical re-reading of Lacan in Female Impersonation, Symbolic ${ }^{7}$ identities, such as the man as the one having the "phallus", that is, as the almighty centre of the social world of linguistic communication and ideological conventions, can be understood as self-fetishisation: That is, as the result of a process of simultaneously knowing about one's essential "lack" and disavowing it via its projection onto the other. As a fundamental forming principle that allows for the displacement and veiling of that one does not have - the denial of Symbolic "castration"- such fetishisation is found in any Symbolic identity and does not necessarily take the penis as its only point of reference, but also 'whiteness' or 'bourgeois' (2003: 51-52). In other words, the adoption of a Symbolic identityTyler, following Lacan and Baudrillard, speaks of 'masquerade' as a copy without an original - is always a fetishistic dilemma. For any Symbolic masquerade can only be realised in the denial of one's own difference, that is, the denial of the fact that there is an indissoluble difference between the I in its wholeness and the I "realised" in the Symbolic order.

However, while everyone by entering the Symbolic order has to submit to its laws and therefore lacks wholeness, in a patriarchal-androcentric society it is the self-fetishisation of the man's lack (manqué) - the devalourisation of woman - that is systematically reconstructed and normalised into a legitimation for male dominance. Based upon the strategic misinterpretation of anatomical differences, "woman" is made to signify "lack" for "man". As the object of his desire, the one not "having"- a penis, subjectivity, (self-) narrative coherence etc.—but "being had", she exists only to make him "whole" (ibid.: 18-23). Yet, whereas this opens up the position of power and subjectivity for man, woman can only "realise" her "self" symbolically as this "other". This makes the fetishistic dilemma even more complicated, for approximation to that position-masking oneself with 'phallic womanliness'-may guarantee to a certain extent intelligibility within the phallocentric order of the Symbolic, but nevertheless does so by reproducing its negation of female subjectivity, that is, forces women to 'reject an essential part of her femininity, namely, all of her attributes in the masquerade' (Lacan 1977: 289-290 cited in Tyler 2003: 20).

To think of possibilities of being-woman apart from phallic womanliness, therefore, has always been a central task in feminist movements and feminist theory. As Tyler summarises, the demand for equality as postulated by liberal feminists during the second wave of feminism can be understood as an early example of such an

7 In this paper I follow the convention of writing the Symbolic with a capital ' $S$ ' when referring to the Lacanian concept of the linguistically structured world of inter-subjective relations, one of the three structures of human existence besides the Imaginary and the Real. 
approach. However, the problem with this demand for equality is that the "natural and originary "full humanity" whose "recovery' or rather unconditional realisation-liberal feminism demands for women under the slogan 'equality', is nothing more than the position of the (white) male as constructed in capitalist patriarchy, which the woman through her "transsexual" assimilation then reinforces in its "universality" (Tyler 2003: 5). Similar problems can be raised with regard to theorisations of female identity or specificity that are based on the assumption of a universal female corporeality, e.g. the procreative body and, by extension, motherhood. This is not only because, here again, being-woman is thought of only in difference to being-man and the (universalised) male body, but also due to the fact that this kind of argumentation more often than not assumes the female body as something prediscursive and, in doing so, ignores the differences in the social production and perception of non-white female bodies (ibid.: 6-11).

According to Tyler, a possibility to think being-woman without making reference to universal corporeality or in difference to "man" can be found in the concept of mimicry. For, as Tyler argues, through the playful repetition or parodist adaptation of existing concepts of womanliness, the woman produces knowledge about womanliness, namely 'that it is a role and not a nature' (ibid.: 23). As a postmodern practice '[c]haracterised by irony, hyperbole, parody, italicization, pastiche, and quotation, mimicry is ... reappropriating a "canonical" text so as to call attention to the gap between the sign and the referent, the signifier and the signified' and shows, that the specificity of being-woman-female difference-has to be understood through contrasting it with various concepts and forms of womanliness (ibid.: 22-23). Nevertheless, so Tyler warns us, caution is to be exercised. For one, there is the problem of linking the subversive potential of mimicry to the (presumed) intention of the mimicry-performer. For, as Joan Riviere demonstrated in Womanliness as Masquerade (1929), "phallic" womanliness is always already a "mask" and therefore different from being-woman, the female I in its wholeness. Hence, it becomes questionable to what extent this difference and that praised as being subversive in the case of mimicry can be distinguished from one another. That is, if both "phallic" womanliness and mimicry are ways of 'female impersonation' - masquerade as copy without an origin - then the (presumed) intention of the mimicry-performer is first and foremost an interpretative intervention by post-modern reception, which implements a dichotomy that allows for one masquerade to be seen as the "original" ground from which mimicry then can differentiate itself (ibid.: 25-29). Another problem is that, in the case of mimicry, the distance or 'gap' from the 'canonical text' is not just postmodern play with signs. As differentiation it can also contribute to or constitute the forming of identity, hence functioning fetishistically. This means that a certain style or form of womanliness serving as "mask" for the mimicry-performer can function-as does "woman" in the phallic Symbolic for "man"-as the other. If then it is ethnically, socially, or/and culturally different womanliness that is made use of 
in female mimicry, certain forms of womanliness-e.g. that of the white, western middle-class woman - in effect get re-inscribed into discourse as the "original", the "ground" on which mimicry is performed (ibid.: 29, 53-58).

\section{The "Woman" Behind the Phalli}

That Tyler's reformulation of fetishism within the context of female subjectivity proves helpful in the understanding of Kusama's artistic texts becomes obvious, when we re-read through it the group of works that is commonly referred to in secondary literature when questions regarding gender and sexuality in Kusama's work arise: the Accumulation series. For such a re-reading will show that it is exactly in the theoretical blind spot of the art-critical intervention pointing towards parody (cf. ibid.: 234-235) that one can get a glimpse of an alternative Kusama: one who-paradoxically in a deeply phallic manner-attempts to differentiate herself from stereotypical concepts of womanliness. This is a feature we later find in her literary texts as well.

Picture 1 Accumulation No.2 (1962)

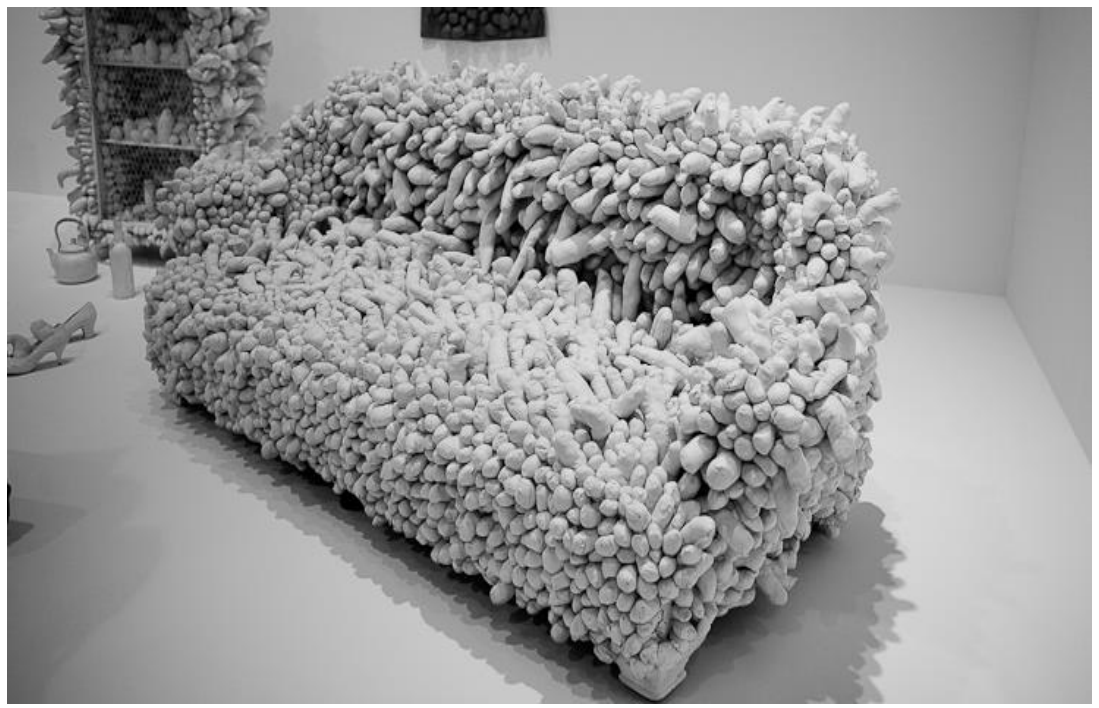

Source: http://www.lemodalogue.fr/site3/yayoi-kusama-accumulation-self-obliteration/

Representative of a series of sculptural works created by Kusama in the early 1960s, the soft-sculpture Accumulation No. 2 is made up of furniture - an ordinary household object (the sofa) - that is covered with a countless number of sewn stuffed fabric in the form of phalli painted white (picture 1). Its basic formation principle of repetition and accumulation brings forth a layered structure, which, according to 
Munroe, can be understood as being gendered. By covering 'living-room furniture, the kitchen-utensils, the bureau' with phallic protuberances, so she suggests, Kusama addresses the subject of 'domesticity', the feminised private space of the home, while her 'violent possession of and control over not one but thousands of penises' represents 'a victory, the freedom from subjugation, from dependency and the glorious right to dominate back' (1989: 12, 23-24). Similarly Tatehata Akira 建畠哲 speaks of Kusama as 'at first attempting to eliminate "the home" in which she sought but could not find solace', 'the woman's space', which 'appears to be buried beneath the minacious penises', and concludes in unison with Munroe that it is the 'hidden woman' that in the end dominates them (Tatehata 1998a: 189).

In Munroe's and by extension Tatehata's symbolic reading, Kusama and "woman" is only thought of in relation to "man". The phalli do not only symbolise patriarchal dominance; this stand-in for the male penis is also that one must have, the privileged signifier for freedom. Yet they are indifferent to the implications of this symbolic inversion of patriarchal hierarchy. They ignore that this means the reproduction of the same oppressive structure. For, if Kusama is symbolically 'dominating back', then this necessitates someone or something being dominated. Actually, this is what Tatehata first sees and then overwrites with his second look: Kusama burying the female space of the home. In other words, what the Accumulation series shows us is not the relation of a "woman" to "man"; it is "woman" dominating "women". For, if those soft-sculptures symbolise an "identification" of Kusama with the (masculinised) position of the possessor of the "phalli", this coincides with her "burying" the "woman". Within the phantasmatic realm of Accumulation No.2 we therefore find not two, but at least three layers or positionalities: (1) The woman possessing and controlling the "phallus"; (2) the woman "burying" the woman; and (3) the "buried" woman. What makes this an ambivalent "trinity" is the fact that Kusama as "woman" can be said to occupy all three of those positions simultaneously; an ambivalence that Munroe and Tatehata try to resolve by reading it in terms of before/after, that is, as a temporal sequence of ascension from the "female" position of (3) to the "male" position of (1) as indicated by Munroe's use of the idiom 'dominating back', or Tatehata's 'at first' (mazuまず).

However, it is important not to overlook that it is the fetishistic act of (2) resulting in (3) that allows for arriving at the position (1) in the first place. Lynn Zelevansky has read this as the parodist visualisation of 'male-fetishism' (1998: 18), which is an argument similar to that by Mignon Nixon, who wrote that

if anything, the Accumulations burlesque the uncanny, spoofing its Freudian explanation - the male subject's repressed desire for his original home, the genitalia of the mother-by converting masculine anxiety into a feminine phallic obsession (Nixon 2012: 183).

8 彼女はまず、そこに心の慰安を求めてかなえられることがなかった“家庭”を抹殺しようとする。 ‘女の場所” は威嚇的なぺニスの下に埋もれたかに見える。だが、その異様でもありユーモラスでもある光景は戦闘的 な意図の裏返しであって、実は’隠された女’こそが無数のペニスを所有し傲然と支配しているのだ。 
Whereas one cannot deny this possibility, it seems that this tendency towards a parodistic reading, however, results from the view that fetishism is a male-only phenomenon. But as Carol-Ann Tyler has demonstrated in Female Impersonation, "lack", "castration", and consequently fetishism are first and foremost Symbolic, epistemological and, in addition, not necessarily penis-centred concepts. Consequently,

woman can fetishize her wound, just as man does. She can disavow her castration, just as man does. And just like man, she makes use of projection to that end. But the victims of this defence mechanism are not always men but also women- 'other' women (Tyler 2003: 49).

Even if then - or rather, exactly because - we can read into the layered structure of Accumulation No.2 a postmodern parody of classic male fetishism, this does not foreclose the possibility of it being "just" (modernistic) fetishism for Kusama. For not only do we have to bear in mind that 'conscious intentions are as much an effect as a cause of history' (Tyler 2003: 31), that is, that Kusama's supposed intention to 'burlesque' fetishism is first and foremost a product of a postmodern art-critical intervention, but also that the alleged excessiveness of the Accumulation series hinting at parody - the ostentatious repetition and multiplication of the phallic form - is actually consistent with fetishism. With regard to the argument that, if femininity as masquerade is fetishistic, the exaggeration seen in female mimicry must be a critical parody of it, Tyler states: '[T]the multiplication of fetishes is consistent rather than disruptive of fetishism, as Freud's discussion of the psychic significance of the snakes on the head of Medusa makes clear' (ibid.: 29).

But what would it mean to say that Accumulation No.2 functions fetishistically? It would mean that, if what the sofa symbolises is the feminine space of the "home", Kusama's multiplication of phallic protuberances can be thought of as a defence mechanism against the threat of "castration" seen in, or rather, the "lack" projected onto the "'other" woman'. That is to say, Accumulation No.2 could just function similar to Medusa's head covered with snakes, which in Freud appears as the visualisation of the fetishistic disavowal of the castration complex. It is presented as the symbolic stand-in for the female's/the mother's genitalia, whose sight at once makes the male stiff with fear of being castrated by the father-as the mother due to the "lack" of a penis is believed to be-while also making him stiff with arousal, thereby simultaneously mitigating this fear by allowing for a re-focusing of attention away from the "castrated" woman to the fact that he still has a penis; a fetishistic disavowal that directs the young boy towards an identity of heterosexual masculinity, that is, of not being but "having" "woman" (Kofman 2003: 165-167; Freud 1941: 47-48). Therefore, by simultaneously presenting the "home", covering it and, in doing so, re-focusing attention to the symbolic possession of "not one but thousand phalli', the Accumulation series could be read as a reification of female fetish- 
ism of imposture; that is, as the symbolic claim for a female I in difference to being the other of patriarchy, to womanliness confined to the "home".

\section{The 'Woman' Behind the Nets}

This becomes more obvious, when compared to the so-called Infinity Net Paintings (cf. picture 2), about which Kusama wrote that she drew the "white nets from morning 'till night, encapsulating the soundless death behind nothingness [represented by the] black dots' ${ }^{9}$ (Kusama 1975: 114). Not only does the sofa that symbolises "home"/"hidden woman" of the Accumulation series occupy the same structural position as the black ground of 'soundless death' beneath the white nets of the Infinity Net Paintings, that is, the position of being on display whilst simultaneously being covered. In one of Kusama's earliest works and prototype of the Infinity Net Paintings (cf. Tatehata 1998b: 67), it is also the figure of her mother that appears on the side of 'death' - covered by a veil of dots (picture 3) - bringing again to mind fetishism. For in classic psychoanalytical terms, it is the sight of the maternal body - the mother's genitalia as the entrance to the former Heim ("home"), the imaginary origin of all things strange yet close, of all things to be covered and yet seen, of things un-heimlich ("uncanny") (cf. Irigaray 1985: 48) - whose status of being "castrated", of not having, results in a feeling of threat Freud likens to the excitement at the deadly look of Medusa's decapitated head. ${ }^{10}$

Just as Medusa's "castrated" head induces horror and excitement, Kusama's drawing of her mother too brings forth ambivalent feelings. Yoshimoto Midori argues that ' $[\mathrm{w}] \mathrm{hile}$ this drawing can be interpreted as Kusama's attempt to eliminate her mother with dots, it can also be seen as a visualisation of her identification with her young and beautiful mother' (2005: 49). She is led to this conclusion by Kusama herself, who explained this drawing as follows: 'I don't know whether dots are part of her or me - it's an illusion. It is about how I wanted to eliminate my mother or erase myself. Because of society's expectations' (Kusama cited in FriisHansen 1994: 50). Once again, we find "woman", that is, Kusama, on both sides of the cover: As the one eliminating and the one potentially being eliminated.

9 この白い網は無の背後の、音のない死の水玉を包んで、私は朝から晚まで描いていた。

10 No need to say that this is but the self-normativising and self-justifying product of patriarchal phallocentrism (cf. Cixous 1976: 885; Creed 1993: 110-111; Tyler 2003: 29, 53). 


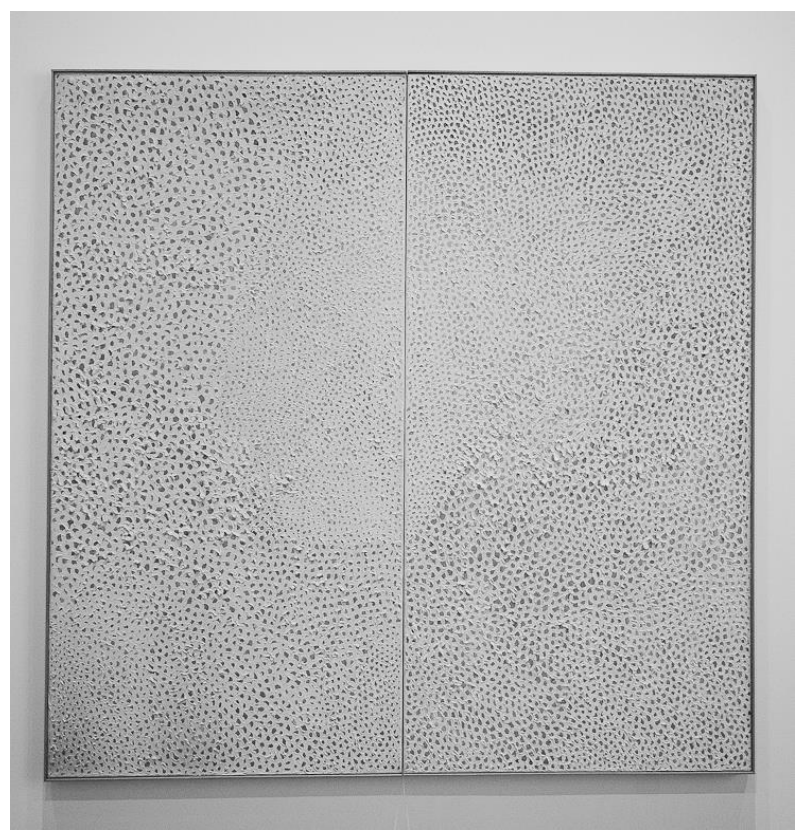

Source: http://www.lemodalogue.fr/site3/yayoi-kusama-accumulation-self-obliteration/

As Tyler argues, " $[\mathrm{t}]$ he significant factor in the fetishism of imposture (of having the "phallus") is that the distance between the fetishist and his object collapses' (2005: 53). In order to sustain the phantasma of a unified identity, "lack" is to be repeatedly projected onto the other, that is, disavowed. Hence, the "lack" one sees in the other-for instance, the male subject of the phallocentric Symbolic sees in "woman"is first and foremost one's own. That is why male fetishism of imposture in a society based upon a binary gender system is, according to Tyler, a constant "disidentification' with "woman". One could also say that fetishism as "self-defence" is always already self-denial, that is, partial self-erasure (ibid.).

In Kusama's account of the drawing, it is not only in the position of being 'eliminated' or 'erased' by dots that the distance collapses between her and her mother, but also in being the (potential) object of social expectations. Thus, we can say that it is social expectations that eliminate both. This is congruent with the 'hidden woman' in Accumulation No.2 and the syllogism behind Yoshimoto's suggestion of an identification between Kusama and her mother. Yet again, there is also a Kusama covering the "other" woman, her mother. This structurally resembles the male disavowal of "lack", the fetishistic attempt to gain distance from the mother as the female other in classic psychoanalysis. Yet, re-read through Tyler's concept of 
fetishism of imposture, it can be understood as a woman's defence against the "selfeliminating" social expectations associated with the figure of the mother, as Kusama's ambivalent dis-identification with the $\mathrm{m} / \mathrm{other}$; especially when we remind ourselves not only of Kusama's critique of Japanese women, who allow themselves 'to be shackled by public opinion ... simply waiting to become someone's bride' (cf. ibid.: 230), but also of the fact that it was her mother who more than anyone else opposed her plans of becoming an artist and just wanted to marry her youngest daughter off (Kusama 2011: 61, 71, 73).

Picture 3 Untitled (1939)

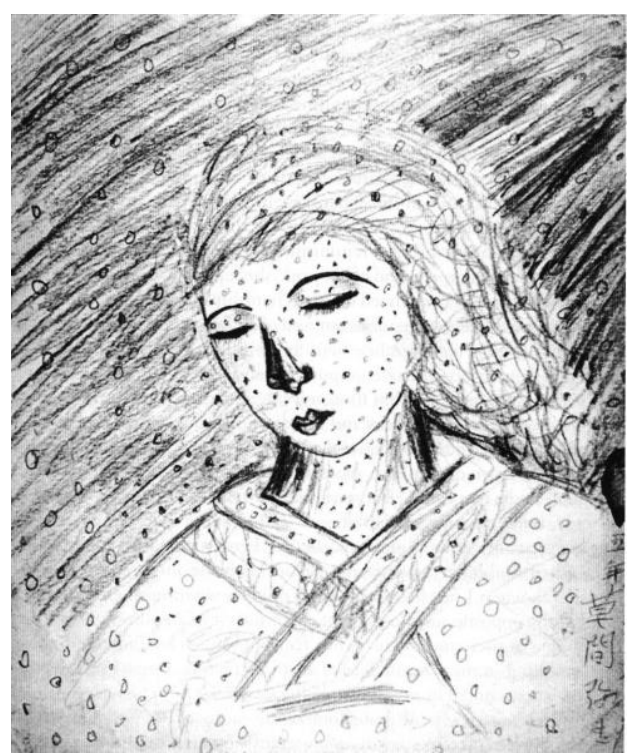

Source: Yoshimoto 2005: 48

Both, the pencil drawing and Accumulation No.2, therefore, can be said to negotiate womanliness. The covering of the mother in Kusama's account of the early pencil drawing makes visible an angst towards the potential in-difference between the female I and social expectations associated with the figure of the mother, while the multiplication of the phallic form in the Accumulation series bespeaks of a female anxiety towards the "home". Accordingly, the phantasmatic position of the one that covers, the one controlling, possessing the "phallus", can be understood as protofeminist claim for an intelligible female I in difference to "home" and "mother".

However, this claim is deeply embedded within a patriarchal, androcentric logic based on the binary notion of "man" and "woman" as universalised, mutually exclusive categories. Kusama accepts the phallocentric equation of woman with "lack" as she reproduces "woman"- the feminine space of the home and the figure of the 
mother - as the other, as the deadly ground from which it is imperative to gain distance; distance formulated as the mimicry-like approximation to a position symbolically associated with the phallic form and, tautologically, the "burying" of "woman". Both works, therefore, can be said to epitomise the dilemma of liberal feminism's claim for "equality" and, consequently, the "transvestic" identity of "phallic women". For it visualises the paradox fact that, in a phallocentric Symbolic, woman can only appear to not "be" but "have" the "phallus" if she distances herself from what symbolises "lack", that is, "woman" as the m/other in its universalised totality and by analogy, that any "transvestic" approximation to the universalised position of "man" as "subject" results in this "phallic woman" being, as Tyler put it, 'at once castrating and castrated' (Tyler 2003: 98-99).

\section{Writing In/Difference to the M/Other-Rijin käten no shüjin (1984)}

Actually, it is this dilemma that we then find reworked in Kusama's early literary work, as is the case with Rijin käten no shüjin $\left(\mathrm{RKNS}^{11}\right)$, Kusama's first novel that is set in Japan. It tells the story of a dysfunctional family in 1940s Japan and, with the suicide of Kīko キーコ, the female protagonist, comments on the difficulty for women in a patriarchal androcentric society to articulate female subjectivity, to differentiate her "self" from the m/other.

\section{Synopsis of Rijin kāten no shüjin}

Kîko, her three sisters, and one brother live together in a small desolate house in an unspecified rural mountain valley somewhere in the Japanese Alps (cf. RKNS 99, $105,127)$. Similar to the only vaguely hinted location, the third person narrator also does not give any concrete information about the time setting. Based on the parenthetical mentioning of food shortage during a war (ibid.: 126), we could assume the intra-diegetic time being somewhere around the outbreak of the Sino-Japanese War in 1937, or after the attack on Pearl Harbor in $1941 .{ }^{12}$ But rather than the hardships of Kîko's family during war time, RKNS depicts the personal suffering of Kỉko. Neglected by her father Gorō ゴロー, a 'pathological Casanova' (byōtekina onna kurui 病的な女狂い, ibid.: 93), Kīko is at her mother's mercy, who abuses her physically and psychologically (ibid.: 92), and repeatedly makes her trail her father

11 Since there exists no official translation of $R K N S$, all translations are by the author. The citations refer to the first reprint of the anthology Kurisutofā danshō kutsu by Juritsu shobō (Kusama 1989b: 87-180).

12 Strictly speaking, one could also argue for the depicted period to be around the time of the Russo-Japanese war. However, the fact that a neon sign is mentioned suggests a time setting not earlier than the mid-1930s, as neon signs started to spread throughout Japan only around that time (cf. Hashizume 2006: 57-58). 
to the brothels, in order to report back to her about his extramarital activities (ibid.: 94). Only the world behind the eponymous 'curtains of depersonalisation' (rijin kāten 離人カーテン, ibid.: 168), the world of hallucinations (cf. ibid.: 87-88, 142144), provides a safe refuge to her. However, Gorō's situation escalates as his debts with a crime syndicate increase, resulting in his disappearance and the family losing their home (ibid.: 150). Now being completely in her mother's clutches, who time and again tells her that it would have been better if she had died at birth (cf. ibid.: 167), Kīko grows more and more desperate. After being told also by her fatherwho as it turns out decided to live with one of his mistresses - that she and her siblings should not have been born in the first place (ibid.: 160), Kîko throws herself in front of a speeding train (RKNS 176-177).

As Hayashi notes, RKNS is an autobiographical text (2007: 135). This is evident, for instance, from the depiction of the dysfunctional family. Mamako ママコ, the mother, as hysteric, dominating woman from a good family (RKNS 105; cf. Kusama 2011: 61, 112); the father as incorrigible womaniser and adopted son-in-law (RKNS 134; cf. Kusama ibid.: 70); the motif of the daughter trailing the father on his way to the brothel (e.g. RKNS 115-116; cf. Kusama ibid.) - all of this can be found in similar wording in Kusama's autobiography. Also, the expressions Kusama uses to describe her own hallucinatory experience and psychic state of feeling cut off from the world, such as rijin kankaku 離人感覚 or rijin kāten, match those used in RKNS for Kīko's hallucinations and psychic state (e.g. RKNS 87-88, 142, 168; cf. Kusama ibid.: 87). Both Infinity Nets' Kusama and RKNS's Kīko experience visual hallucinations in the form of proliferating flowers covering their surroundings (e.g. RKNS 90; cf. Kusama ibid.: 69). Furthermore, if RKNS intra-diegetic time setting is the 1930s or early 1940s, then Kîko, who experiences her first period towards the end of RKNS, is nearly the same age as Kusama, who was born in 1929. In the light of this, one could then, as Munroe suggests, read RKNS as Kusama retelling her childhood traumata; therefore, Kīko as the young Kusama, and Kīko's suicide as Kusama processing her own suicidal thoughts of, for instance, wanting to jump in front of a Chuō line train in Tōkyō, as she wrote in her autobiography (Kusama 2011: 93).

\section{Rejecting the World Rejecting Me}

But Kìko's suicide can also be read allegorically. It is depicted as the rejection or the result of being rejected by what Kìko calls sekkusu jigoku セックス地獄 ('sex hell', RKNS 163), that is, the world dominated by the never ending fights between her parents about her father's affairs; a world unevenly structured along the lines of gender. Hence, RKNS allows for two conflicting interpretations of Kîko's suicide: It may be read as 1) the "inescapable" result of a family constellation, in which a strong father figure is missing and as 2) the rejection of a world defined by the 
equation of woman $=\mathrm{m} /$ other. And it is exactly this ambivalence where the potentially private becomes political, where RKNS becomes a proto-feminist negotiation of womanliness.

We can, for instance, find this sense of rejection expressed in the following quote:

Kīko doesn't know how to climb the blue hills of adolescence. What is up this 'hill of unintelligibility'? [...] Right there, before climbing 'the hill of unintelligibility', before adolescence arrives, tainted by the humiliation of the adults' denial of her existence [...], Kīko wanted to end this abominable cycle of life and death (RKNS 169). ${ }^{13}$

Similarly, that for Kỉko her first period is an 'ominous sign' (fukitsu na shinboru 不吉なシンボル; ibid.: 112) is due to being a 'sign of becoming an adult' (otona e no shirushi 大人への印; ibid.: 118). It makes her aware of the fact that she, too, as potential mother, will take part in the reproduction of the 'adult world' (otona sekai 大人世界; ibid.), this 'cycle of life and death' so 'abominable' (imawashii rin'ne tenshōいまわしい輪廻転生; ibid.: 169) to her:

Menstruation is an ominous sign. Why? Because it means you can now give birth to despicable children. Worthless, stupid, and filthy - that's what children are. Mamako preached this view to Kinko and the others on a daily basis. [...] The first period is the loathsome, blood-smeared gateway to the endless cycle of birth and death (RKNS 112, cited in translation in Würrer 2015b: 77-78). ${ }^{14}$

But why is the first period frightening and detestable to Kìko? Because it signifies the possibility of her giving birth to 'despicable children' like herself? Or because it signifies the possibility of bearing children like her mother? The importance of this passage lies exactly in its ambiguity.

On the one hand, Mamako appears as the dominant, abusive mother and the object of paranoiac hallucinations:

A voice out of nowhere. "Kīko, Kīko" it repeatedly echoes. Kīko, Kīko. Who was this voice repressing Kinko's self? [...] The fourth time she heard her name being called from behind where no one was, Kīko realised it was the phantom of her mother. [...] From her early childhood on Kīko was bereft of the possibility to establish an independent, individual self. For the sake of her mother she tailed her father, turned his mistresses' dining table upside down, cleaned up after her parents' fights. Bound hand and foot to her, she also

13 キーコは、青春の蒼い丘へのぼる術を知らない。あの「しらずの丘」には何があるのか。 $[\ldots]$ 生をうけたこと を大人たちが拒否した屈辱にまみれた青春の来る前に「しらずの丘」の手前で、[...] いまわしい輪廻転生 を破棄し滅亡させようと思った。

14 メンスは不吉なシンボルである。なぜなら、いまわしい子供ができるからだ。駄目で思昧で薄污い。それが 子供だ。ママコがキーコたち子供に毎日のようにそれを言いきかせている。[...] 初潮はいまわしい傷痕に まみれた輪廻転生への初発展だ。 
stayed at home from school. The more her mother used her for her own purposes, the more Kìko fled into the curtains of depersonalisation (RKNS 143-144). ${ }^{15}$

The mother not letting go of the daughter, making thus impossible the autonomous realisation of her "self", her subjectification: This is classic othering of the mother as "phallic m/other". Kusama's text thus brings to mind Lacan's explanation of the paternal function:

The mother's role is her desire. [...] Her desire is not something you can bear easily, as if it were a matter of indifference to you. It always leads to problems. The mother is a big crocodile, and you find yourself in her mouth. You never know what may set her off suddenly, making those jaws clamp down. That is the mother's desire (Lacan 1991: 129 cited in Fink 1996: 56).

Against this threat of being devoured by the crocodile - a variant, one could argue, of the vagina dentata myth (cf. Creed 1993: 2-8, 105-122)-Lacan then recommends remedy in the form of the "phallus", which he compares to 'a roller, made of stone' jamming open the crocodile's mouth to protect us 'should the jaws suddenly close' (Lacan ibid., cited in Fink 1996: 57). Posing the threat of an eternal prolonging of the pre-Symbolic, undifferentiated mother-child dyad-the 'lethal embrace' (Valente 2003: 167) - the mother qua crocodile or phallic mother, functions like Medusa in Freud: as a fetishistic phantasma sustaining the phallocentric Symbolic. As the m/other threatening not to let go of her "phallus", that is, her child, she "necessitates" and "justifies" the paternal function of jamming in the 'roller', of differentiating the "same" from the "other", leading the boy into the Symbolic where he can become subject. While the boy, however, can leave behind the m/other, differentiation from the $\mathrm{m} / \mathrm{other}$ is extremely difficult for the girl. For it is exactly becoming m/other what the phallocentric Symbolic demands of women (Tyler 2003: 98). And it is this difficulty that RKNS articulates when it depicts the mother not as "just" being psychologically and physically abusive, but causally links Kïko being completely at the hands of her mother - the lack of distance between mother and daughter - to her inability to formulate an autonomous self; her being the prisoner of the curtains of depersonalisation, which, in the end, leads to her suicide. This fear of being too close can be said to signify Kîko's desire for a female self in difference to the $\mathrm{m} / \mathrm{other}$. Still, the portrayal in the form of paranoia is problematic. For, as Tyler notes with regards to the phantasma of the "phallic mother": "When the fantasy is paranoid and the lack of difference figured as fearful, it cannot be progressive for

15 無人の中の声。声は、こだまとなって「キーコ、キーコ」と連呼しつづけるのだ。キーコ、キーコと、キーコの 自我を押さえつけるものは一体誰の声だろう。[...] キーコは四度目に自分の名前を無人の背後から呼ば れたとき、その声は幻の母だとさとった。[...]キーコには幼い日より自分を独立した一個の個人の人間とし て育成していく過程が失われていたのだ。母の自我のため、父を尾行したり、メカケの食卓を引っくりかえ したり、夫婦喧嘩の後始末をしたり、学校へ行くこともなく、母の手足とされてきた。母が彼女自身のために キーコを使えばつから程キーコは一層離人カーテンの中に逃亡しつつあった。 
women; it contributes to the repudiation of femininity that patriarchy already engenders' (ibid.: 99).

On the other hand, however, RKNS reveals an understanding for the character of Mamako, the mother. We find her portrayed as a "prisoner" in a loveless marriage, in which she nevertheless, for her part, remains monogamous out of moral dutydespite romantic advances on the part of a servant, always hoping that Gorō will still leave his mistress and come home again (RKNS 147-149, 152). She is also a prisoner in a society where, as Kīko bemoans, 'wives, for men, are nothing but birthing machines', ${ }^{16}$ while men go from one woman to the next (ibid.: 131). This is all the more frustrating for her mother because, while 'Gorō sought for a woman gentle like his mother', Mamako, 'born as only child', actually has a 'tomboyish nature, always flatly contradicting men ${ }^{17}$ (ibid.: 105). The frustration and even desperation on account of her captivity, the gap between her nature and social expectations, between her being-woman and the role of housewife and mother are given as reasons for her violent behaviour towards her children (ibid.: 149). Indeed, Kinko's world is dominated by her mother; but it is the father at whose mercy ultimately the mother, and by extension Kīko, are left. RKNS recognises Mamako's hardships as "other" of patriarchy, or as Kiko puts it, that 'this chaos everyday is due to dad's penis romping around' (ibid.: 108). ${ }^{18}$

Thus, RKNS and its protagonist Kìko oscillate between fear of and identification with the mother. This indecisive stand towards the mother is also mirrored in the stance the text takes towards the father. We find Kîko 'again looking at her father with hateful eyes ${ }^{19}$ and expressing her contempt for him as she confronts him at one of his mistresses' houses and shouts to his face: 'You don't need to come home again ... You shitty pig of a father! I wish you'd just die from syphilis!' (RKNS 109). ${ }^{20}$ At the same time, Kinko longs for her father as the one who could put a stop to her mother's outbursts (e.g. RKNS 101); a longing which finds its most intense expression in Kīko's incestuous sexual fantasy about her father (RKNS 115-116).

\section{The Ambivalence of Killing Oneself}

Kîko's suicide is neither just the "inevitable" result of the internalisation of her mother negating her subjectivity — the 'deadly embrace' with the/her m/other-nor just the rejection of the social equation of "woman" with the role of the mother and

\footnotetext{
16 妻などという立場は、男にとって子供を生む機械に過ぎない。

17 ゴローは $[. .$.$] 母親のような女、優しい女を求め [. .$.$] 一人娘に生まれたママコの、男まさりでいつも男に対$ 抗しようとする性質と相容れないのは当然だった。

$18[\ldots]$ 毎日のゴタゴタは、父の股の間にあるペニスが騷ぐからだ $[\ldots]$ 。

19 父を再び憎しみの心を抱いて見た。

20 二度と家へかえってこなくてもいいんです。[...]くそ、豚のような父親よ。梅毒で死んだ方がましだわ。
} 
reproduction. It is both; and as such, it is simultaneously both acceptance and critique of the androcentric phallic order. If we take the mother as one of the victims of a patriarchal Japan in which 'dad's penis romps around' as it pleases, Kīko's suicide can be understood as the rejection of an 'adult world' in which woman sacrifices the possibility of an autonomous self in order to meet society's expectations, that is, to become housewife and give birth like her mother. If, however, we read her dropping out of the 'abominable cycle of life and death' as the "inevitable" consequence of the dominant $\mathrm{m} /$ other being too close and driving the daughter into the world of hallucinations, then Kīko's suicide suggests - exactly as the horrifying result of its failure - the "necessity" of the patriarchal, phallocentric order, where the roller is to be jammed into the crocodile's mouth, where the father puts the m/other in her place.

We find, therefore, reworked in RKNS the subject of Kusama's untitled pencil drawing when read through her own interpretation of it: the difficulty of female disidentification from/with the m/other. The reason why Kiko in the end rejects the 'world of adults' as a whole is exactly because society makes it impossible for her to claim a female identity apart from the concept of mother. As her first period makes her realise, taking part in the 'world of adults' as woman is to become mother, that is, potentially like her own mother. Yet it is exactly her mother who is portrayed as the one negating her subjectivity, the m/other from whom it is instructive to gain distance. Consequently, dropping out completely, erasing the self, is paradoxically the only way of autonomously articulating her identity, that is, her being in difference to this 'abominable cycle of life and death', the reproduction of a world where being-woman equals becoming $\mathrm{m} /$ other.

\section{Writing In/Difference to the M/Other-Kurisutofā danshō kutsu (1984)}

Just as Kusama left Japan in order to break free from her mother "bullying" her into marriage and realise her self in difference to the role of housewife and mother, the dilemma RKNS portrays is "resolved" when the text is set in the United States instead of Japan. For, as is the case with Kurisutofā dansho kutsu $\left(\mathrm{KD}^{21}\right)$, in the United States the woman is able to differentiate herself from the other. Through the fetishisation and abjection of Henry ヘンリー, the black hustler and protagonist of

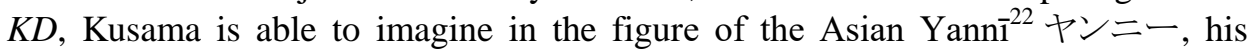
female pimp, a woman in difference to "lack".

21 Citations refer to the first reprint of the anthology Kurisutofā danshō kutsu by Juritsu shobō (Kusama 1989a: 5-84), while for direct quotations I use Ralph McCarthy's translation (Kusama 1998: 9-69).

22 While McCarthy romanises this name with a single 'i' (see quotes below), I transcript it with a macron above the ' $i$ ' in order to reflect the long vocal in the original ヤンニー. 


\section{Synopsis of Kurisutofā danshō kutsu}

On a Saturday night in a summer around the late 1960s (cf. KD 69), drug addict Henry, in desperate need of money, asks his fellow student at New York University and pimp Yannī to fix him up with a customer. She is able to do so and the two meet with the potential customer, Robert Greenberg, at a restaurant. Soon they agree on 'six hundred dollars for a week with Henry', after which Greenberg takes Henry to his summerhouse in New Jersey (KD 18; Kusama 1998: 17). However, Henry, in withdrawal, soon loses his temper, venting at Greenberg his homophobic anger:

I am only here because I want the money! You probably believe I'm a homo just 'cause Yanni told you I am. But every time I have sex with a man I end up wantin' to bash his fuckin' brains in! Goddamn it! Buyin' my ass for a week for a lousy six hundred bucks! You fuckin' Jewish prick! (KD 31; Kusama ibid.: 27).

Henry immediately apologises and resumes performing his masquerade as the penetrable sex toy, his duty to 'surrender [his] anus freely to the client to do with as he sees fit' as Yannī consistently preached to him (KD 42; Kusama ibid.: 35). Only ' $[\mathrm{h}]$ is anus ... was maintaining a mute resistance' as Greenberg repeatedly attempts inserting his penis into Henry's rectum (KD 41; Kusama ibid.: 34). However, as Greenberg succeeds and his penis 'begins to run amok, ramming against the soft inner walls' (KD 53; Kusama ibid.: 43), Henry faces his limit and in a fit of hallucinatory withdrawal cuts off Greenberg's penis (KD 53-57; Kusama ibid.: 44-47). Letting Greenberg bleed to death, he leaves the summerhouse in panic and heads towards downtown New York, where Yannī, after learning about what happened in New Jersey, decides to help Henry flee. Confused, both leave his apartment without a plan where to go and end up at the top of the Empire State Building, from which Henry in the last scene leaps to death:

[...B] racing herself, she looks back to where Henry ought to be standing. Her heart stops. His body has vanished from that space. Yanni runs to the railing and looks down. In the milk-colored mist a single black spot. Falling. The spot grows smaller and smaller, until it's just a dark speck dissolving into the mist. The crows that were pecking away at their blood-red fruit lift up into the air as one, and with their backs to heaven they form a ring and chase the black speck toward earth (KD 83-84; Kusama ibid.: 64-65).

\section{Black Skin, Yellow Skin}

The sculptures' 'protrusions are positive and the spaces between them negative' Kusama wrote about her Accumulation series in her autobiography (Kusama 2011: 47). Just an unspecified binarism there, we find Henry at the end of $K D$ leaping right into a similar space: the one between the Empire State Building 'he couldn't help 
but see ... as a phallus' (KD 28; Kusama 1998: 24) and the other skyscrapers, turning, in unison with the crows, his back to heaven, leaving back on top of that gigantic phallic protrusion only his female pimp Yannī. The 'single black spot' he dissolves into as in the 'milk-colored mist' also reminds us of Kusama's visual art, as it brings to mind the black dots of 'soundless death' being encapsulated by the white, grey, and milk-coloured meshes of the Infinity Net Paintings. And it reminds us once again of fetishism, when we consider that Henry's suicide, or rather, his disappearing into the 'milk-colored mist' actually is but another incident in (the climax of) a series of (fetishistic) coverings. For, together with Yann̄̄ arbitrarily entering Henry's 'sweat-and-urine-scented' apartment, we find him "flickering", that is, alternately visible and invisible, already in the first scene of $K D$ :

A shadow wriggled amid the fetid heat and sat up on wrinkled gray bed sheets. After each flash of the strobe light Henry's bird's-nest Afro melted into the deep purple darkness. When a split second later the light flashed again his body was floating there in the room like a ghost swimming through space (KD 8; Kusama ibid.: 9-10).

A 'shadow' on 'gray bed sheets', Henry is at once seen and 'melting' into darkness, appearing to us only as illusion or 'ghost', as McCarthy translates the original gen'ei 幻影. Another incident of Henry being seen covered is when he and Yannī climb the stairwell of the Empire State Building:

Yanni's face presses against something soft and sticky. She draws back and looks at Henry. The dark skin of his face, too, is embossed with a virginal white spider's web, a net of countless octagonal meshes (KD 79; Kusama ibid.: 61).

While in the first scene the colour of the sheets only vaguely hints at the Infinity Net Paintings, the 'net of countless octagonal meshes' here does even more so. We should also pay attention to the fact that we again find Yannī in spatial proximity to the "flickering" Henry and her face, too, 'embossed' with the net, but it is only Henry's face where the 'long-legged spider continues silently to spin its beautiful silky white thread' (ibid.). It is as if $K D$ in analogy to Kusama looking at her untitled pencil drawing, poses the question whether the nets are a part of Yannī or Henry.

And, indeed, we can understand these extremely visual incidents of Henry being at once "on display" and covered as one facet of $K D$ 's fetishistic portrayal of Henry. Another is Yannī oscillating between the identification with and rejection of Henry as can be seen in the following passage:

As a little girl in Hong Kong, Yanni had lost her virginity to her own father, who'd raped her in the bath. From then on he'd forced himself upon her regularly. [...] By no means, therefore, was she unaware of the malice behind her efforts to match up young canaries with pederasts. It was true she had some sympathy for Henry, however, if only because he was a 'nigger' in a racist country. This though his black skin, normally a disadvantage, gave him a leg up in the queer world. White men viewed Negro youths as an extremely 
desirable prize. Henry's blackness and considerable beauty inspired in Yanni a mixture of love and hate, and her feelings about doing business with him were ambiguous, like those of an art dealer selling a fine art work (KD 64-65; Kusama ibid.: 51).

From the beginning of $K D$ we find Henry - either in withdrawal or high-being dependent on Yannī. She is the one deciding whom he sleeps with and the price, while also being the one having ambivalent feelings towards him. As if exacting vengeance towards men for the sexual violence she had to experience by her father, she 'casually' sells "her" boys 'as if they were cakes wrapped in pretty paper and tied with ribbons' (KD 45; Kusama ibid.: 38), making them the penetrated ones. But at the same time, Henry is not just kept at distance as the object of her 'malice'. He is also shown sympathy and understanding, for him being the racial other.

Given that sex work in $K D$ is likened to art dealing as in the quote above, one could argue that with $K D$ Kusama intended to write a parable of an art world in which, as she herself experienced during the Zen-boom of the 1960s, (self-) exoticisation — selling (your) racial difference and (your) "coloured" skin—redounds to one's advantage (Zelevansky 1999: 23; Kusama 1998: 24). That Henry was sold for 600 dollars, which is just within the range of the price an art work by Kusama made when she first started out in New York's art scene (350 to 800 dollars according to Yoshimoto [2005: 55]) may be pure happenstance; but, when read in context, this detail strengthens the impression of $K D$ 's subject being the objectification of racial difference or race as commodity fetish. So does Henry, who, when confronted by his brother about him working as a hustler, compares himself to artists '[ ...] sleepin' with the art collectors or the museum directors' to get ahead (KD 22; Kusama ibid.: 20). Such a reading would also find support in that the Empire State Building not just looks like a phallus to Henry but it's windows are compared to 'dollar bills' (KD 28; Kusama ibid.: 24) and, therefore, could be said to symbolise the complicity of phallocentrism and capitalism.

Although it might be tempting to then read the castration of Greenberg, the buyer of Yannī's 'art work', as symbolic attack on this complicity, we should, however, not forget that in order for $K D$ to function as that kind of parable or satire, it is not only blackness that would have to be the stand-in for Kusama's 'coloured' skin. Since no "exaggeration" means no (critical) gap, it would also need to be "hyperbolically" so, implying a hierarchisation of races at the heart of $K D$; and, conversely, we would need to forget that there actually is a 'yellow woman', 'the petite, exotic type of lady' of Asian descent (KD 50; Kusama ibid.: 60), that is, Yannī. But she is there; and she is not the one being the object of exoticisation but the one "having" it. While sympathising with Henry, she objectifies him, renting out his body to others with 'tremendous satisfaction' (Kusama 1998: 50). It is his body that is not only repeatedly seen covered but made the object of an eroticising gaze. Henry's 'dazzling beauty' is emphasised-likened to 'an antelope carved from black diamonds' 
(KD 33; Kusama ibid.: 29) —with '[h]is skin [...] extraordinarily dark, even for a black person' at constant display (KD 16; Kusama ibid.: 17). A sight we also find Yannī being dazzled by as she sees him, once again covered by a 'filthy sheet' (Kusama 1998: 51): 'The round, well formed black mounds of his buttocks, with their faintly purple gemlike luster, captivated Yanni's gaze' (ibid.).

Henry, in other words, is the fetishised racial "other". As projection surface, he allows Kusama to imagine another female I in difference to being made the object of an eroticising and exoticising, that is, othering gaze. For, if we take into consideration that the experience of being "othered" on the basis of race is, if anything, first and foremost Kusama's 'wound' (Tyler 2003: 49), then making not the yellow skinned Asian woman Yannī but Henry the 'fine art work', the racialised object of desire and consumption of - not only but also- the yellow skinned Asian woman constitutes a fetishistic disavowal of that "wound' or image of "lack". Hence, $K D$ can be read as a dis-identification with Henry as the bearer of the sign of "lack" in the person of Yannī, the Asian woman who overlaps with (the author) Kusama in objectifying Henry. Furthermore, her ambiguous attitude of being torn apart between love and hate, sympathy and malice also bespeaks of the fact that the "lack" projected onto and disavowed in the "other" may be first and foremost one's own, that is, of the Asian woman Kusama's 'lack' (cf. Tyler 2003: 53). The text, by repeatedly making Henry be seen covered - his black body at once (erotically) displayed and "veiled"-mirrors Yannīs "ambiguous" feelings; an ambiguity finally resolved as Henry leaps into the milk-coloured mist, turning into a black spot of soundless death, turning over the phallic Empire State Building to Yannī.

\section{Claiming the Empire State Building}

Henry's leap can be understood as the last incident of a series of fetishistic coverings or, in other words, as the symbolic climax of the phallicisation of Yannī as another Kusama. This suggests a striking resemblance between this last scene with one from Manhattan jisatsu-misui-jōshühan (1978). In the latter, another Kusama, its protagonist Kusama クサマ, already climbs to the rooftop of the Empire State Building to discard what was once part of her and, in doing so, actually not only suggests that Henry's leap is abjection but that onto Henry we also find sexual difference projected:

[...] To the Empire State Bilding! Scatter my genitals that I drew in the darkness of the toilet, the drawing paper I embosomed, here from the roof of this skyscraper; it shines flattering in the wind, I can see it scattering all over New York Bay. It flies so high. [...] Look at the sky! My vagina, it dances in the air. Yay! The gays pausing down there, looking up from their lunch in the garden of the New York Library. What's that, dancing in the sky? 
They hug each other and kiss. Doubt that what's up dancing in the sky is a vagina (Kusama 1978: 29-32, translated by the author). ${ }^{23}$

It is indeed not Kusama's vagina that is dancing in the sky. In $K D$ it is Henry who falls from the sky, facing the ground. But what needs our attention here is not only the fact that, if we compare those two scenes, Kusama and Yannī (moving up) as well as Henry and the vagina paintings (moving up and down) fall together, but also that the spot Henry turns into as he turns his back to heaven, coincides with the dark toilet, also located in the imaginary space somewhere 'down there' between the phallic skyscrapers, from which Kusama and Yannī have arisen. This is because the toilet and, by extension then, the 'negative' space between the phallic skyscrapers (Kusama 2011: 47) can be said to be phantasmatically connected to Japan and, interestingly, to the image of the dominant mother, as the following two quotes suggest.

The people around me started making a fuss. About me gradually following the path of performance art although [she] has brought me into this life to become a bride; they threw away my brushes and the paint, the paintings I have drawn, out there to the riverside behind [the house]. [...] Since I couldn't do it elsewhere anymore, I started drawing hidden in the toilet. Took a hand mirror and went in. You know what I am talking about, right? I drew hundreds of paintings of my genitals on drawing paper cut in quarters. [...] I call that 'toilet art'. The door of the toilet was always closed. My mother mistook it for being broken and got in a rage, banging and kicking the door. Me inside, my heart pounding fast (Kusama 1978: 23-24, translated by the author). ${ }^{24}$

This is the account the Kusama of Manhattan jisatsu-misu-jōshuhan gives of the toilet, and we find a similar passage in Kusama's autobiography:

At one point I went through a phase when I enjoyed snipping off the heads of flowers. I would toss the tight blossoms into a hole I had secretly dug, until I had accumulated hundreds of them. I also drew pictures of flowers in full bloom, the petals of which formed shapes that resembled vaginas. The dots in the centres represented penises. Whenever my mother was on the warpath, I would take refuge in the lavatory. Inside, with the latch secured I felt safe at last and free to draw sheet after sheet of these sexual flowers. [...] I called these pieces 'Toilet Art' (Kusama 1998: 113).

$23[\ldots]$ エンパイア・ステート・ビルへ。トイレットの暗がりで描いた幼い日の私の性器を、抱きしめた画用紙、 摩天楼のビルのテッペンからばらまく、ヒラヒラと風に光って 吹かれている、ニューヨーク湾に散らばって いくのが見える。ずいぶん高く舞い上がっている $[. .$.$] あっ空をみて！わたしのヴァジャイナ、舞っていく。$ ヤーイ。立ちどまってみている男色たちが、ニューヨーク図書館の庭のランチに芝生でスカイ見上げてい る。何、あれ。舞っているもの。男たちは男に抱きづいてキッスしている。空、舞っていく形、あれがヴァジ ヤイナだとは思えないよ。

24 お嫁にいくために生んでやったのに、次第に舞台芸術づいていくわたしに、周りが騒ぎだして、エノグ箱 も筆も、描いた絵も、ウラの河原に投げられちやったの。[...] 絵が描けなくなったわたし、お便所でかくれ て描いたわ。手鏡もって入って。分る。これ。なんのことか。何百枚も四ッ切りの画用紙に、性器の絵たくさ ん描いたの。これ「トイレット・アート」つていらの。お便所の戸いつも開かないのね。戸がこわれているって 勘違いして、頭に来てしまったお母さん、どんどん戸をたたいたり蹴ったり寸るの。中のわたし胸ドキドキよ。 
In both cases the toilet is a space where the young woman fled to, haunted by society's expectations personalised in the mother, and as such resembles Kîko's hallucination-described, among other things, as proliferating flowers (cf. RKNS 90) - in that both function as pharmakon. Given the autobiographical context of RKNS, we could in fact also make a connection between the ambiguous situation of Kusama and Kusama painting her vaginal flowers alone in the toilet and the ambivalent feelings Kìko has as she experiences her first period, that is, her vagina as potential sexual organ for the first time, which she also experiences in solitude, 'abandoned by everyone' (RKNS 118). ${ }^{25}$

Could we then not think of Henry, too, as Kusama's “toilet art"? That is, could it not be that Henry-who, just like Kîko, experiences hallucinations - is veiled, or rather "discarded", abjected at the end of $K D$ because not only is he the racial "other" but also the projection surface for woman as $(\mathrm{m} /)$ other? Or rather: The stand-in for woman "yet to be" differentiated from the m/other? That is, for the Kusama of the dark toilet fleeing from the mother, which the vagina paintings thrown off the Empire State Building can be said to symbolise, and for RKNS's Kîko?

It is not only Henry's final leap from the Empire State Building that brings to mind Kusama and Kusama's toilet. In fact, his first appearance as well reminds us of those toilets, with Yann̄-like both Kusama and Kusama's mother-arbitrarily opening the door that 'didn't give' at first (KD 6; Kusama 1998: 9); but, as it finally opens, reveals Henry wriggling 'amid the fetid heat', 'beyond ... a wave of sickening sweat-and-urine-scented air' (ibid.). ${ }^{26}$ And, as Furukawa Hideo 古川日出男 notes in his afterword to the 2012 paperback edition of $K D$, there further exists an uncanny analogy between $K D$ and $R K N S$ :

I started asking myself, if I have ever read a novel that inundated with the word 'anus'. This anus, that anus, an endless number of anuses. Yet anuses filled with emotion, accepting and rejecting anuses. [...] In the second novel of this anthology, RKNS, that word becomes 'vagina'. [...] What we have here is the vagina experiencing the first period or the vagina tainted by gonorrhea and syphilis, the vagina being at once organ of pleasure and discomfort, yet alive (2012: 201-202, translated by the author). ${ }^{27}$

Furukawa is right. Both RKNS's 'vagina' and KD's 'anus' are depicted as the object of ambiguous emotions. And in the following we actually find them both metaphorically coalesced into one ambivalent flower: "Henry was sullen in his beauty tonight,

25 誰からも見捨てられた初潮なのだ。

26 In the original text the association is even clearer: 'nekki to benjo no shüki no naka' (熱気と便所の臭気の なか, 'amidst the heat and [nasty] toilet smell').

27 僕は「かつて僕はこれほど作中に“肛門”といらワードがあふれる小説を読んだことがあったか？」と自問し 出すのだ。あの肛門、その肛門、無数の肛門、しかし感情に満ちている肛門、肯定する肚門、拒絶する肛 門。[…] たとえば本書収録の二篇め、『離人カーテン囚人』だとそのワードが“腔”に変わる。 $[\cdots]$ そしてこ こにあるのは、初潮を迎える腔、あるいは淋病や梅毒にまみれる䄇で、快楽器官であると同時に不快で、 しかし生きている。 
an uncanny "rose" whose thorns drew blood with every touch' (KD 46; Kusama 1998: 38). ${ }^{28}$ 'Rose' (bara 薔薇) is here used synonymously for 'Henry's angry forbidden door' (Henrī no okotta 'hirakazu no doa' ヘンリーの怒った「開かずのド $ア\lrcorner$ ) in the following sentence (ibid.), that is, for his “anus" (kōmon 肛門) being in 'mute resistance' against Greenberg's penis (KD 41; Kusama ibid.: 34). This is a metaphorical connection the word as such might already be said to indicate, as it is also 'an antiquated slur for gay men' (Ishii et al. 2014: 40).

Yet this rose - one of Kusama's "flowers"-also inscribes onto Henry and his 'anus' the image of 'vagina', of Kusama and Kusama's sexual flowers, and in doing so again makes $K D$ hint at what we might already suspect: Namely, that it is exactly for the reason that this rose is sullen and thorny that we find mirrored the potential dilemma of all "flowers", of Kusama and Kusama's "toilet art". For it is Henry who-similar to women in a patriarchal-androcentric Symbolic-sees himself confronted with the necessity of fulfilling the role of the penetrable and own-able object of male desire in order to be (socially) viable. This masquerade - reminiscent of phallic womanliness - time after time makes him wanting to get high; and, finally, leads him to castrate his client. It is the projection of this role onto Henry which makes it possible for Kusama to imagine in the character of the Asian Yannī a woman differentiated also from the experience of being dominated and sexually objectified as woman, without having to sacrifice becoming or being woman as such.

\section{An Uncanny 'Rose'}

In RKNS the possibility of ending the 'abominable cycle of life and death', the reproduction of the ever same 'world of adults', is actually only a dream, a hallucination of Kìko, in which she sees herself demolishing her father's and mother's genitals with fireworks (RKNS 164). Henry castrating Greenberg therefore-in anal-ogy - could be seen as the realisation of Kiko's hallucinatory attack on the 'world of adults'. But if so, why does Henry only attack Greenberg, whereas Kīko attacks mother and father, woman and man? Where did the mother go?

Actually she is right there. As the word bukimi na 不気味な (“uncanny”) in the quote above indicates (see n. 28), we can find traces of her, that is, of the mother qua crocodile, precisely in Henry himself:

28 McCarthy translates bukimi na 'bara' in the original phrase 'sawaru to toge ga te ni chi o nijimaseru yō na bukimina “bara”" (さわると手に血を滲ませるような不気味な「薔薇」) without the single quotation marks for bara ("rose") as 'a forbidding rose'. Since the adjective bukimi na is also the term used to translate the psychoanalytical concept of the uncanny, a nuance as important in the understanding of the text as the single quotation mark emphasising the metaphorical function of bara, I have decided to adapt the English translation accordingly. 
The moth that had bumped its wings against the rim of the cup and scattered its scales was now sinking in a sea of coffee, its entire body saturated with caffeine. Henry suddenly and inexplicably sat up, took the cup from the table, and drank what remained of the coffee (KD 46; Kusama 1998: 38).

Without a warning and for whatever reason, Henry's 'jaws clamp down' (Lacan 1991: 129 cited in Fink 1996: 56) and he swallows the moth. We can find this motif of an insect being incorporated already in one of Kusama's earlier works. Regarding the 1965 photograph/performance of her lying in her soft-sculpture My Flower Bed (picture 4), she gives us the following interpretation:

Now I am an insect that returns to its flower during the night; the petals close over me as the mother's womb protects an unborn child [...] Until dawn, the flowers in My Flower Bed will sway in the night breeze and caress me gently, for the night is the time of love and sex (Cremer 1965 cited in Yoshimoto 2005: 67).

Picture 4 Kusama in her soft-sculpture My Flower Bed (1965)

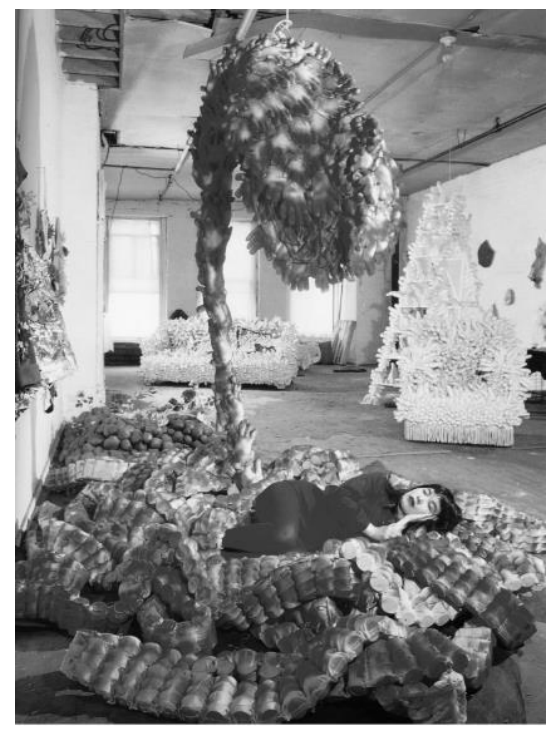

Source: LA County Museum of Art. Kusama, 1958-1968. New York: D.A.P., 1998: 44

As Yoshimoto emphasises, however, this flower is not just caressing. It is also threatening (ibid.). For, as Kusama adds, they are 'flowers that trap insects in order to devour them' (Cremer 1965 cited in Yoshimoto 2005: 67). As we already know, flowers are a metaphor for female genitals in Kusama's texts. But here the flower is also likened to the mother's womb, posing the threat of devouring Kusama qua insect. 
Symbolic female genitals posing the threat of incorporation: What this resembles is the myth of the vagina dentata. As Barbara Walker writes, the vagina dentata is the classical symbol of men's fear of sexual difference, the sexual other, 'expressing the unconscious belief that a woman may eat or castrate her partner during intercourse' with her fanged vagina (1983: 1036). Barbara Creed further elaborates that in psychoanalysis the vagina dentata is explained either as 'symbolic expression of the oral sadistic mother' - the mother feared by female and male infants for potentially feeding not them but feeding on them - or as 'expression of the dyadic mother, the all-encompassing maternal figure of the pre-Oedipal period who threatens symbolically to engulf the infant, thus posing a threat of psychic obliteration' (1993: 121), like Lacan's m/other qua crocodile. Both, therefore, 'stress the incorporative rather than castrating aspect' and thus bespeak of the fact that the origin of the vagina dentata myth lies not in the female genitals but, as Walker shows, the mouth (1983: ibid.). It is an image of two body openings, which coalesced over time, as exemplified by the Lacanian crocodile with its threatening fanged mouth as symbol for the m/other. And it reappears in My Flower Bed - the (vaginal) flower posing the threat of devouring Kusama qua insect-which we, in analogy to Mamako making Kîko her 'hand and feet' in RKNS, can read as the representation of fear towards being devoured by the mother, that is, towards the m/other who in her 'deadly embrace' threatens with annihilation of the "self".

Ultimately we find this symbolism again in Henry - the uncanny rose, being anus and vagina at once - as he engulfs the moth. That Henry's mouth fellating Greenberg right after the moth-incident appears 'like a petunia popping open in black space' and not only 'the whites of his eyes' but also his 'teeth were glowing savagely in the night like the gaze of an animal lurking in the shadows ... waiting for prey' (KD 47; Kusama 1998: 39), further reinforces the impression that in Henry's "flowers"- petunia and rose - phantasmatical traces remain of the fanged "mouth" of the crocodile-mother.

\section{Deadly Circles}

However, Henry reminds us of the vagina dentata not just when he flashes his teeth and swallows the moth. A few pages later he actually castrates a man; and in doing so makes us incapable of deciding whether Greenberg's castration was the work of Henry as the "crocodile-mother" or the revenge attack of Henry as the stand-in for Kusama and Kusama from the dark toilet and by anal-ogy Kỉko of RKNS, the women pressured to put on a mask of (sexual) passivity.

But, again, it is this undecidability that constitutes the most important characteristic of $K D$ and makes it readable as a proto-feminist negotiation of womanliness. 
For, in depicting Henry as this Janus-faced "flower", $K D$-like $R K N S$ - oscillates between affirmation and rejection of the phallocentric order.

Both possibilities coalescing in Henry's 'flower' suggests that they are linked in a vicious cycle. Just as Kusama's and Kusama's mother, animated by social expectations (and in order) to marry off their daughters, bang at the doors of the toilets, so Yann̄ arbitrarily enters Henry's 'sweat-and-urine-scented' room and-knowing of her malice and the satisfaction this gives her-fixes Henry up with men, reinforcing her status as the dominant woman, that is, his pimp. And Henry leaves his "toilet", sets out into the world of 'take the money, here's my asshole' (KD 45; Kusama 1998: 38) and, finally, stretched to the limits of his perseverance, castrates and kills his client. As we can see from this brief comparison, the mothers of Kusama and Kusama, as well as Yannī, drive their "phalli" into the arms of men. All three are, in other words, accomplices in the patriarchal and phallocentric merry-go-round. But if that is the case, why then did not Henry (also) attack Yann̄̄? Because Yann̄- like Kusama, Kusama, and Kìko's mother, that is, like any "phallic woman"-is only "castrating"/dominating in being "castrated"/dominated herself. They too are victims of this patriarchal and phallocentric merry-go-round. This becomes obvious when we once again think of the fact that Henry coalesces with Kusama in the toilet, while Yannī does so with Kusama (staying) on top of the Empire State Building. Accordingly, Kusama's mother can as well be thought of having-like Yann̄ = Kusama = Henry - at some point hidden in the toilet. In this sense, we could also see in Greenberg's castration an expression of dissent by the "phallic woman", that is, Kusama's mother and Yannī.

But Kusama and Kusama are, as the last scene of KD symbolises, unable to break out of this vicious circle. For both dispose of their "toilet art" - the vagina paintings and Henry-by assigning them the same place the "hidden woman" of the Accumulation series inhabits: The 'negative space' between the phallic protuberances, the space of 'deadly silence' beyond the milk-coloured mist, where the toilet is and where all initially started.

\section{Conclusion}

Alexandra Munroe once wrote that the success Kusama had as a writer was a sign 'that avant-garde literature has traditionally been more appreciated and supported in Japan than the visual arts' (1989: 33). Whether Kusama's prose actually can be called avant-garde or not is a question for future discussion. However, as this paper has shown, we can at least read Kusama's early literary work as 'a sign of the poison of and a cure for an impossible situation' (Pollock 2000: 108). Both KD and RKNS were written in the late 1970s and published in the early 1980s (Hayashi 2007: 133), a time when Kusama was almost completely off the screen of Japan's art world, 
being remembered (if at all) as a 'shameless and infamous woman' (Karia 1989: 94). This situation might have led her, as Seki Naoko suggested, to reformulate "her" 1960s and re-present her artistic self. What we can say with certainty is that at least her early prose texts allow for such a reading; that is, a reading of $K D$ and $R K N S$ as the reformulation of the critical negotiation with femininity as seen in Kusama's earlier visual art.

In $R K N S$ we find expressed the difficulty of the girl-becoming-woman to differentiate herself from the mother in a world 'that requires that confusion' (Tyler 2003: 98). This dilemma then constitutes the point of departure for $K D$, in which the woman appears in difference not only to the experience of being the racial other but also the $\mathrm{m} / \mathrm{other}$, that is, Yannī in difference to the black hustler Henry. Of course, both of the novels illustrate, as is obvious from character and location settings, autobiographical traits. But we should not forget that, as feminism has told us, the private is not just the personal world of the individual, located somewhere at the periphery of history, but is always already political. In Kīko's suicide and Yannī's "survival", $R K N S$ and $K D$ formulate not only the difficulty for woman to become subject in an androcentric patriarchal world but also the desire for a female $I$ in difference to pre-given concepts of womanliness. In doing so, they not only concretise Kusama's visual art-namely the proto-feminist subtext of the untitled pencil drawing from 1939 and her Accumulation series-but also become themselves proto-feminist negotiations of womanliness. At the same time, however, it should also be noted that these are negotiations deeply embedded in a phallic and, in the case of $K D$, also racist and homophobic logic.

Similarly then, the fact that Kusama-vis-à-vis a Japanese-speaking readership - attributes to the two locations (Japan and the United States) such different possibilities of being a woman can be understood not just as a simple re-presentation of her personal past experience but as a critique of her home country: A place where - as Kusama herself had been forced to experience - self-realisation as woman apart from being wife and mother (for example, as a female artist) was extremely difficult, if not utterly impossible. 


\section{LIST OF ABBREVIATIONS}

KD

RKNS
Kurisutofā danshō kutsu

Rijin kāten no shüjin 


\section{REFERENCES}

Borggreen, Gunhild. "The Myth of the Mad Artist: Works and Writings by Kusama Yayoi." In Copenhagen Journal of Asian Studies, 15, 2001, pp. 10-46

Borggreen, Gunhild. "Gender in Contemporary Japanese Art." In Gender and Power in the Japanese Visual Field, edited by Joshua S. Mostow, Norman Bryson, and Maribeth Graybill. Honolulu: The University of Hawai'i Press, 2003, pp. 179-200

Bullock, Sandra. The Other Women's Lib: Gender and Body in Japanese Women's Fiction. Honolulu: University of Hawai'i Press, 2010

Butler, Judith. Gender Trouble: Feminism and the Subversion of Identity. London and New York: Routledge, 1990

Butler, Judith. Bodies that Matter: On the Discursive Limits of "Sex". London and New York: Routledge, 1993

Butler, Judith. "Conscience Doth Make Subjects of Us All." In Yale French Studies, 88, 1995, pp. 6-26

Cixous, Hélène. "The Laugh of the Medusa.” Translated by Keith Cohen et al. In Signs 1/4, 1976, pp. 875-893

Creed, Barabara. The Monstrous-Feminine: Film, Feminism, Psychoanalysis. London and New York: Routledge, 1993

Cremer, Jan. "On the Cover: My Flower Bed (Painted Cloth) by Kusama." In Art Voices 4/4, 1965

Dawsey, Jill Christina. "The Uses of Sidewalks: Women, Art, and Urban Space 1966-1980." Ph.D. diss., Stanford University, 2009

Fink, Bruce. The Lacanian Subject: Between Language and Jouissance. Princeton: Princeton University Press, 1996

Freud, Sigmund. "Das Medusenhaupt.” In Gesammelte Werke, Vol. 17, edited by Anna Freud. Frankfurt a. Main: Fischer, 1941, pp. 47-48

Friis-Hansen, Dana. "Yayoi Kusama's Feminism.” In ART+TEXT, 49, 1994, pp. 48-55

Godzik, Maren. Avantgarde Männersache? Künstlerinnen im Japan der 50er und 60er Jahre des 20. Jahrhunderts. München: Iudicum, 2006

Hayashi, Yōko 林洋子. “Kusama Yayoi - Kaku koto ni tsukareta 'sōsaku no shūjin”” 草間彌生一 書くことに憑かれた『創作の囚人』[Kusama Yayoi: A Prisoner of her Creativity]. In Aube Hikaku geijutsu オーブ比較芸術学 [Aube - Comparative Art], 3, 2007, pp. 131-141

Hashizume, Shin'ya 橋爪神也. Modanizumu no nippon モダニズムの日本 [Modernism's Japan]. Tōkyō 東京: Kadokawa Gakugei Shuppan 角川学芸出版, 2006

Irigaray, Luce. Speculum of the Other Woman. New York: Cornell University Press, 1985

Ishii, Anne, Chip Kidd, and Graham Kolbeins, eds. Massive: Gay Erotic Manga and The Men Who Make It. Seattle: Fantagrafic Books, 2014

Karia, Bhupendra. "Biographical Notes." In YAYOI KUSAMA: A Retrospective, edited by Bhupendra Karia. New York: Center for International Contemporary Arts, 1989, pp. 67-105

Kofman, Sarah. “A Feminist Reading of Freud's Medusa.” In The Medusa Reader, edited by Marjorie Garber. London and New York: Routledge, 2003, pp. 165-167

Kuroda, Raiji 黒ダライ児. Nikutai no Anākizumu. 1960 nen-dai nihon-bijutsu ni okeru pafōmansu no chikasuimyaku 肉体のアナーキズム 1960 年代・日本美術におけるパフォーマンスの地下 水脈 [Anarchy of the Body: Undercurrents of Performance Art in 1960s Japan], Tōkyō 東京: Guramu bukkusu グラムブックス, 2010

Kusama, Yayoi 草間爾生. “Mina-san, panti o nugisutemashō” 皆さん、パンティを脱ぎ捨てましょ う [Ladies, Let's Burn our Panties]. In Josei sebun 女性セブン [Woman's Weekly], 1 (April), 1970, pp. 44-45 
Kusama, Yayoi 草間彌生. “Waga tamashī no henreki to tatakai” わが魂の遍歴と闘い [Odyssey of My Struggling Soul]. In Geijutsu Seikatsu 芸術生活 [Art Life], 11, 1975

Kusama, Yayoi 草間彌生. Manhattan jisatsu misui jōshūhan マンハッタン自殺未遂常習犯 [Manhattan Suicide Addict]. Tōkyō 東京: Kōsakusha 工作舎, 1978

Kusama, Yayoi 草間爾生. “Kurisutofā danshō kutsu” クリストファー男娼窟 [The Hustler's Grotto of Christopher Street]. In Kurisutofā danshō kutsu クリストファー男娼窟, edited by Kusama Yayoi. Tōkyō 東京: Juritsu Shobō 而立書房, 1989a, pp. 5-84

Kusama, Yayoi 草間爾生. “Rijin kāten no shūjin” 離人カーテンの囚人 [Prisoner of the Curtains of Depersonalisation]. In Kurisutofā danshō kutsu クリストファー男娼, edited by Kusama Yayoi. Tōkyō 東京: Juritsu Shobō 而立書房, 1989b, pp. 87-180

Kusama, Yayoi. The Hustler's Grotto: Three Novellas. Translated by Ralph McCarthy. Berkeley: Wandering Mind Books, 1998

Kusama, Yayoi. Infinity Net: The Autobiography of Yayoi Kusama. Translated by Ralph McCarthy. London: Tate Publishing, 2011

Lacan, Jacques. Ecrits: A Selection. Translated by Alan Sheridan. New York: W.W. Norton, 1977

Lacan, Jacques. Le Sèminaire: Livre XVII, L'envers de la psychoanalyse. Paris: Seuil, 1991

Munroe, Alexandra. "Obsession, Fantasy and Outrage: The Art of Yayoi Kusama." In YAYOI KUSAMA: A Retrospective, edited by Bhupendra Karia. New York: Center for International Contemporary Arts, 1989, pp. 11-35

Munroe, Alexandra. "Between Heaven and Earth: The Literary Art of Yayoi Kusama." In Love Forever: Yayoi Kusama, 1958-1968, edited by Los Angeles County Museum of Art. Los Angeles: Los Angeles County Museum of Art, 1998, pp. 70-85

Nixon, Mignon. “Infinity Politics.” In Yayoi Kusama, edited by Frances Morris. Tate Modern: London, 2012, pp. 176-185

Nochlin, Linda. "Why Have There Been No Great Women Artists." In Women, Art and Power and Other Essays, edited by Linda Nochlin. New York: Harper and Row, 1988, pp. 147-158

Pollock, Griselda. Vision and Difference: Feminism, Femininity and the Histories of Art. London and New York: Routledge, 1988

Pollock, Griselda. "Three Thoughts on Femininity, Creativity and Elapsed Time." In Parkett, 59, 2000, pp. 107-113

Riviere, Joan. "Womanliness as Masquerade.” In International Journal of Psychoanalysis, 1, 1929, pp. 303-313

Seki, Naoko 関直子. “Kusama Yayoi no nihon ni okeru sōsaku ni tsuite” 草間彌生の日本に おける創作について [On Kusama Yayoi’s Artistic Production in Japan]. In In Full Bloom: Yayoi Kusama, Years in Japan, edited by Tōkyō-to gendai bijutsukan 東京都現代美術館, Tōkyō 東京: Tōkyō-to gendai bijutsukan 東京都現代美術館, 1999, pp. 6-21

Tatehata, Akira 建畠哲. “Sōrei naru obusesshon” 壮麗なるオブセッション [Magnificent Obsessions]. In Toi naki kaitōo 問いなき回答 [Answers Without Questions], edited by Tatehata Akira 建畠哲. Tōkyo 東京: Gōryū sho'in 五柳書院, 1998a, pp. 184-192

Tatehata, Akira. "Kusama as Autonomous Surrealist." In Love Forever: Yayoi Kusama, 19581968, edited by Los Angeles County Museum of Art. Los Angeles: Los Angeles County Museum of Art, 1998b, p. 61-69

Tomī, Reiko. “Shikaku geijutsu hyōshō toshite no aidentiti” 視覚芸術表象としてのアイデンティテ イ [Identity as Visual Representation]. In Art Communications アートコム/現代美術の投稿雑 誌, 6, 1997, pp. 12-23

Tyler, Carol-Ann. Female Impersonation. London and New York: Routledge, 2003 
Valente, Joe. “Lacan's Marxism, Marxism's Lacan (From Žižek to Althusser).” In The Cambridge Companion to Lacan, edited by Jean-Michel Rabaté. Cambridge: Cambridge University Press, 2003, pp. 153-172

Walker, Barbara. The Woman's Encyclopedia of Myths and Secrets. San Francisco: Harper One, 1983

Watanabe, Reiko 渡辺レイ子. “Dokyumento Kusama Yayoi”ドキュメント草間爾生 [Documenting Kusama Yayoi]. In Bijutsu techō 美術手帖 [Art Notes], 45/671, 1993, pp. 80-113

Würrer, Stefan. “Ten to ten no aida no 'onna' - Kusama Yayoi no geijutsuteki katsudō ni okeru ‘joseisei’ o meguru kōshō” 点と点の間の〈女〉一 草間彌生の芸術的活動における〈女性性〉 をめぐる交涉 [The Women in between the Dots: On the Negotiations of Femininity in the Artistic Practice of Kusama Yayoi]. M.A. thesis, The University of Tōkyō, 2015a

Würrer, Stefan. "The Woman Behind the Dots: On Kusama Yayoi's Literary Work.” In Kusama Yayoi: I Uendeligheden [Kusama Yayoi: Infinity], edited by The Louisiana Museum of Modern Art. Copenhagen: The Louisiana Museum of Modern Art, 2015b, pp. 74-79

Yoshimoto, Midori. Into Performance: Japanese Women Artists in New York. New Brunswick: Rutgers University Press, 2005

Zelevansky, Lynn. "Driving Image: Yayoi Kusama in New York." In Love Forever: Yayoi Kusama, 1958-1968, edited by Los Angeles County Museum of Art. Los Angeles: Los Angeles County Museum of Art, 1999, pp. 10-41 
APPENDIX: Kusama Yayoi's Prose Work (in chronological order)

\section{Short Stories (tanpen shōsetsu 短編小説)}

“Kōmon chikyū bijutsu-ron”肛門地球美術論 [Study of an Anal Art World]. In Yū (bessatsu 1, chi-kumi: homoerosu) 遊(別冊、ち組: ホモエロス) [Objet Magazine Yū (Special Issue No. 1, chi-gumi, Homoeros)] 1979, pp. 81-85

“Kurisutofā danshō kutsu” クリストファー男娼窟 [The Hustler’s Grotto]. First published in Yasei jidai 野生時代 [Wild Age], 1, 1984, pp. 360-393 (Later included in the anthology of the same title and its subsequent reprints)

“Rijin kāten no shūjin” 離人カーテンの囚人 [Prisoner behind Curtains of Depersonalisation]. First published in Yasei jidai 野生時代 [Wild Age], 4, 1984, pp. 192-212 (Later included in the anthology Kurisutofā danshō kutsu and its subsequent reprints)

“Shishū Akashia" 死臭アカシア [Death Smell Acacia]. First published in Yasei jidai 野生時代 [Wild Age], 5, 1984, pp. 182-190 (Later included in the anthology Kurisutofā danshō kutsu and its subsequent reprints)

“Onna no sono” 女の園 [The Garden of Women]. First published in Yasei jidai 野生時代 [Wild Age], 9, 1984, pp. 132-153 (Later included in the anthology Ten to chi no aida [1988])

“Jitsuroku - senshokuhi himitsu kessha” 実録・染色屁秘密結社 [Annals of the Secret Shart Society]. In Yū (bessatsu 3, he-kumi: kuso aruiwa yūtopia) 遊(別冊、へ組: 粪あるいはユート ピア) [Objet Magazine Yū (Special Issue No. 3, he-gumi, Shit, or: Utopia)], 1985, pp. 92-95

“Ten to chi no aida” 天と地の間 [Between Heaven and Earth]. In Ten to chi no aida 天と地の間 [Between Heaven and Earth], Tōkyō 東京: Juritsu shobō 而立書房, 1988, pp. 77-151

“Numa ni mayoite” 沼に迷いて [Straying around the Moor]. In Numa ni mayoite, Tōkyō 東京: Juritsu shobō 而立書房, 1992, pp. 5-82

“Kosute kusahara” 子捨て草原 [The Field of Abandoned Children]. In Numa ni mayoite, Tōkyō 東京: Juritsu shobō 而立書房, 1992, pp. 83-108

"Nyūyōku eizu”ニューヨーク・エイズ [New York - AIDS]. In Nyūyōku monogatari ニューヨーク 物語 [Stories of New York], Tōkyō 東京: Juritsu shobō 而立書房, 1993, pp. 5-72

“Dauntaun”ダウンタウン [Downtown]. In Nyūyōku monogatariニューヨーク物語 [Stories of New York], Tōkyō 東京: Juritsu shobō 而立書房, 1993, pp. 73-137

“Ari no seishin byōin” 蟻の精神病院 [The Madhouse of Ants]. In Ari no seishin byōin 蟻の精神 病院 [The Madhouse of Ants], Tōkyō 東京: Jiritsu shobō 而立書房, 1994, pp. 3-84

“Baisekushuaru” バイセクシュアル [Bisexual]. In Ari no seishin byōin 蟻の精神病院 [The Madhouse of Ants], Tōkyō 東京: Jiritsu shobō, 1994, pp. 85-108

\section{Novels (chūhen shōsetsu 中編小説, chōhen shōsetsu 長編小説)}

Manhattan jisatsu-misui-jōshūhan マンハッタン自殺未遂常習犯 [Manhattan Suicide Addict]. Tōkyō 東京: Kōsakusha 工作舎, 1978

Sento marukusu kyōkai enjō 聖マルクス教会炎上 [The Burning of St. Marks Church], Tōkyō 東京: Paruko shuppan パルコ出版, 1985

Uddosutokku inkei kiri ウッドストック陰茎斬り [Woodstock Phalluscutter]. Tōkyō 東京: Peyoruto shuppan ペヨルト出版, 1988

Itami no shanderia 痛みのシャンデリア [Chandelier of Pain]. Tōkyō 東京: Peyoruto shuppan ペヨルト出版, 1989 
Shinjū Sakuragaoka 心中桜ヶ丘 [Double Suicide in Sakuragaoka]. Tōkyō 東京: Juritsu shobō 而立書房, 1989

Kēpu koddu no tenshi-tachi ケープコッドの天使たち [The Angels of Cape Cod]. Tōkyō 東京: Juritsu shobō 而立書房, 1990

Sentoraru pāku no jigitarisu セントラルパークのジギタリス [The Foxgloves of Central Park]. Tōkyō 東京: Juritsu shobō 而立書房, 1991

Sumire kyōhakuすみれ強迫 [Violet Obsessions]. Tōkyō 東京: Sakuhinsha 作品社, 1998

Nȳūyoku '69 ニューヨーク’69 [New York ‘69]. Tōkyō 東京: Sakuhinsha 作品社, 1999 


\section{GLOSSARY}

\begin{tabular}{|c|c|c|}
\hline bara & 薔薇 & 'Rose' \\
\hline bunraku & 文楽 & $\begin{array}{l}\text { A form of traditional Japanese puppet } \\
\text { theatre }\end{array}$ \\
\hline bukimi na & 不気味な & 'Uncanny' \\
\hline byōtekina onna kurui & 病的な女狂い & $\begin{array}{l}\text { 'Pathological casanova'; term used in } \\
\text { Kusama Yayoi's short story Rijin kāten no } \\
\text { shüjin (1984) to characterise the protago- } \\
\text { nist Kiko's father }\end{array}$ \\
\hline chōhen shōsetsu & 長編小説 & $\begin{array}{l}\text { Novel with a length of over } 250 \text { manu- } \\
\text { script pages (genkō yōshi 原稿用紙) à } 400 \\
\text { signs }\end{array}$ \\
\hline chūhen shōsetsu & 中編小説 & $\begin{array}{l}\text { Novel of middle length corresponding to a } \\
\text { length of about } 120 \text { to } 250 \text { manuscript } \\
\text { pages (genko yoshi 原稿用紙) à } 400 \text { signs }\end{array}$ \\
\hline fukitsu na shinboru & 不吉なシンボル & $\begin{array}{l}\text { 'Ominous sign'; term used as metaphor for } \\
\text { the Protagonist's first period }\end{array}$ \\
\hline Furukawa Hideo & 古川日出夫 & Author (b.1966) \\
\hline gen'ei & 幻影 & 'Illusion’ \\
\hline Gorō & ゴロー & $\begin{array}{l}\text { Character in Kusama Yayoi's short story } \\
\text { Rijin kāten no shüjin (1984); father of the } \\
\text { protagonist Kîko }\end{array}$ \\
\hline harenchi & 破廉恥 & $\begin{array}{l}\text { A noun meaning 'scandal', 'shameless- } \\
\text { ness'. Also used as adjective in the sense } \\
\text { of 'shameless', 'indecent', 'infamous' }\end{array}$ \\
\hline Hachijō-jima & 八丈島 & $\begin{array}{l}\text { Japanese Island in the Pacific Ocean south } \\
\text { of Tōkyō. Used as exile for convicts until } \\
\text { the Meiji Restauration in } 1868\end{array}$ \\
\hline Henry & ヘンリー & $\begin{array}{l}\text { One of the two main characters of Kusama } \\
\text { Yayoi's short story Kurisutofā danshō } \\
\text { kutsu (1984) }\end{array}$ \\
\hline $\begin{array}{l}\text { Henrī no okotta } \\
\text { 'hirakazu no doa' }\end{array}$ & $\begin{array}{l}\text { ヘンリーの怒った } \\
\text { 「開かずのドア」 }\end{array}$ & $\begin{array}{l}\text { 'Henry's angry forbidden door'; metaphor } \\
\text { used in Kusama Yayoi's short story } \\
\text { Kurisutofā danshō kutsu for Henry's, one } \\
\text { of the main characters' 'anus' }\end{array}$ \\
\hline imawashii rin'ne tenshō & いまわしい輪廻転生 & 'abominable circle of life and death' \\
\hline Izumi Kyōka & 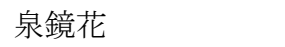 & Author (1873-1939) \\
\hline Joryū bijutsu & 女流美術 & $\begin{array}{l}\text { "Female art"; term to categorise works by } \\
\text { female artists }\end{array}$ \\
\hline Juritsu shobō & 而立書房 & Publishing company \\
\hline Kadokawa shoten & 角川書店 & Publishing company \\
\hline Kīko & キーコ & $\begin{array}{l}\text { Protagonist of Kusama Yayoi's short story } \\
\text { Rijin kāten no shüjin (1984) }\end{array}$ \\
\hline kōmon & 肚門 & anus \\
\hline Kubota Shigeko & 久保田茂子 & Artist (1937-2015) \\
\hline $\begin{array}{l}\text { Kurisutofā danshō } \\
\text { kutsu }\end{array}$ & クリストファー男娼窟 & $\begin{array}{l}\text { Kusama Yayoi's third prose work and } \\
\text { most well known short story; published in } \\
1984\end{array}$ \\
\hline
\end{tabular}




Kusama Yayoi
Mamako
Manhattan jisatsu-
misui jōshuhan
Murakami Ryū
Nagano
Nakagami Kenji
Ono Yōko
otona e no shirushi
Otona sekai
rijin kankaku
Rijin kāten no shūjin

ryōsai kenbo

sekkusu jigoku

Shōwa

Takiguchi Shūzo

tampen shōsetsu

Tatehata Akira

Tōno Yoshiaki

Yann̄̄

Yasei jidai shinjin bungaku shō
草間彌生

ママコ

マンハッタン自殺未遂

常習犯

村上龍

長野

中上健次

小野洋子

大人への印

大人世界

離人感覚

離人カーテンの囚人

良妻賢母

セックス地獄

昭和

瀧口修造

短編小説

\section{建畠哲}

東野芳明

ヤンニー

野生時代新人文学賞
Artist (b. 1929)

Character in Kusama Yayoi's short story Rijin käten no shüjin (1984); Mother of the protagonist Kīko

Kusama Yayoi's first novel; published in 1978

Author (b. 1952)

A prefecture located at the centre of Japan's biggest main island Honshū Author (1946-1992)

Artist (b. 1933)

'Sign of becoming an adult'

'Adult world'

'Feeling of Depersonalisation'

'Prisoner behind the Curtains of Depersonalisation'. Also translated as 'Prisoner surrounded by the curtains of Depersonalisation'; title of Kusama Yayoi's fourth prose work and third short story (1984), a poem (1978), and painting (1950)

Ideological concept of womanliness in Japan, defining the ideal role of woman in society as good wife and wise mother; dominant from the late Meiji period (1868-1912) until the end of the Pacific War (1937-1945) but influential well until the later Shōwa era (1926-1989)

'Sex hell'; metaphor used in Kusama Yayoi's short story Rijin käten no shüjin to describe the never ending fights between the protagonist Kîko's parents

The period of Japanese history corresponding to the reign of the Shōwa emperor Hirohito from 1926 to 1989 Literary critic and painter (1903-1979) Short story or short novel. Not officially defined in its length but generally said to equate to a text volume of 50 to 100 manuscript pages (genkō yōshi 原稿用紙) à 400 signs

Art critic (b.1947)

Art critic (1930-2005)

One of the two main characters of Kusama Yayoi's short story Kurisutofā danshō kutsu (1984)

Literary award for new writers awarded yearly by the monthly magazine Yasei jidai between 1974 and 1986 